\title{
Litholytic Activities of Natural Bioactive Compounds and Their Mechanism Insights
}

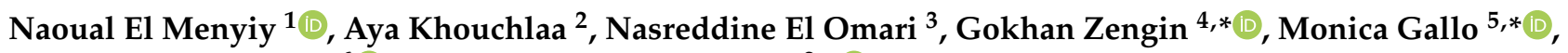 \\ Domenico Montesano ${ }^{6}$ (D) and Abdelhakim Bouyahya ${ }^{2, *}$ (1)
}

1 Department of Biology, Faculty of Sciences Dhar El Mahraz, University Sidi Mohamed Ben Abdellah, B.P. 1796 Fès-Atlas, Fez 30 000, Morocco; Nawal.ELMENYIY@usmba.ac.ma

2 Laboratory of Human Pathologies Biology, Department of Biology, Faculty of Sciences, and Genomic Center of Human Pathologies, Faculty of Medicine and Pharmacy, Mohammed V University, Rabat 10 000, Morocco; aya.khouchlaa@gmail.com

3 Laboratory of Histology, Embryology, and Cytogenetic, Faculty of Medicine and Pharmacy, Mohammed V University, Rabat 10 000, Morocco; nasrelomari@gmail.com

4 Department of Biology, Science Faculty, Selcuk University, Konya 42130, Turkey

5 Department of Molecular Medicine and Medical Biotechnology, University of Naples Federico II, Via Pansini 5, 80131 Naples, Italy

6 Department of Pharmacy, University of Naples Federico II, Via D. Montesano 49, 80131 Naples, Italy; domenico.montesano@unina.it

* Correspondence: gokhanzengin@selcuk.edu.tr (G.Z.); mongallo@unina.it (M.G.); boyahyaa-90@hotmail.fr (A.B.)

check for updates

Citation: El Menyiy, N.; Khouchlaa, A.; El Omari, N.; Zengin, G.; Gallo, M.; Montesano, D.; Bouyahya, A.

Litholytic Activities of Natural Bioactive Compounds and Their Mechanism Insights. Appl. Sci. 2021, 11, 8702. https://doi.org/10.3390/ app11188702

Academic Editor: Alessandra Durazzo

Received: 17 August 2021

Accepted: 15 September 2021

Published: 18 September 2021

Publisher's Note: MDPI stays neutral with regard to jurisdictional claims in published maps and institutional affiliations.

Copyright: (c) 2021 by the authors. Licensee MDPI, Basel, Switzerland. This article is an open access article distributed under the terms and conditions of the Creative Commons Attribution (CC BY) license (https:// creativecommons.org/licenses/by/ $4.0 /)$.

\begin{abstract}
Urolithiasis is a disease characterized by the formation of stones, which are crystalline accretions that form in the urinary tract from minerals dissolved in the urine. Moreover, it is considered to be a complex and multifactorial disease, requiring treatment. Unfortunately, current treatments are insufficient or may induce several side effects. In fact, medicinal plants are among the anti-litholytic treatments that are strongly recommended by many studies. Indeed, these natural resources contain bioactive molecules of different natures, such as flavonoids, terpenoids, alkaloids, and phenolic acids, which have recently demonstrated very important anti-litholytic effects. The molecular mechanisms involved are multiple and variable, and can reach cellular and molecular levels. In this review, we have discussed in depth the work that has studied the bioactive molecules of medicinal plants and their major potential against urolithiasis. Scientific databases, including Web of Science, PubMed, and Google Scholar, were searched from their inception until April 2021.The cellular and molecular mechanisms are presented and discussed. Some mechanisms of action related to these bioactive compounds are highlighted. This review could provide a scientific starting point for further studies on urolithiasis and natural bioactive compounds, especially flavonoids.
\end{abstract}

Keywords: urolithiasis; bioactive compounds; flavonoids; litholytic targets

\section{Introduction}

Urolithiasis (urinary stone disease) is one of the painful disorders of the urinary tract that is caused by the formation of calcific stones in the kidneys, bladder, and urethra [1]. There are numerous types of kidney stones that differ in chemical composition, with more than $80 \%$ of them being composed of calcium oxalate $(\mathrm{CaOx})$, with calcium oxalate monohydrate (COM) as the major form [2].

Epidemiological studies have demonstrated that the incidence and prevalence of kidney stone formation has been increasing in the last forty years, is more predominant in men $(12 \%)$ than in women $(6 \%)$, and is frequent among 20-40 year olds for both men and women [3]. This prevalence may be due to several environmental, genetic, and nutritional factors, such as low urinary volume, dietary habits (diets rich in animal protein), and global warming, as well as metabolic alterations [4]. 
Many methods have been used to treat and curb kidney stones, such as the combination of dietary procedures and surgical as well as drug treatments. However, their serious adverse side effects and recurrence remain as problems to overcome [5]. Furthermore, interest in alternative treatment options has increased. These options include herbal medicines as old as human history that could be useful as an alternative or complementary therapy in the management of kidney stones. In this regard, many plants have been shown to possess anti-lithiasis action [6]. Indeed, several plants currently remain the basis of a large part of the medications used for the prevention and treatment of many diseases due to their content in secondary metabolites [7]. Indeed, in recent years, several studies have provided reliable results on the effects of numerous secondary metabolites such as polyphenolic compounds, flavonoids, stilbenes, tannins, and terpenoids on many diseases, such as kidney stones [8]. These compounds exhibit litholytic effects via their different mechanisms of action. Therefore, the aim of this review was the exploration and highlight of studies on the anti-lithiasis effect of secondary metabolites and their mechanisms of action.

\section{Research Methodology}

The data on natural bioactive compounds from medicinal plants with litholytic effects were collected using different scientific databases, such as Google Scholar, Web of Science, Scopus, ScienceDirect, SpringerLink, Wiley Online, SciFinder, and PubMed. The data were then classified and organized in tables. The IUPAC names of bioactive compounds were checked using the PubChem database and the chemical structures were checked using the ChemDraw Pro 8.0 software.

\section{Litholytic Activity of Flavonoids and Stilbenes}

Several flavonoids and stilbenes such as apigenin, catechin, (-)-epicatechin, curcumin, rutin, hesperidin, resveratrol, hyperoside, and quercetin (Figure 1) have been investigated for their potential to inhibit the formation of kidney stones [2,9-20]. These authors investigated the anti-lithiasis effect of these bioactive compounds by in vitro and in vivo studies on kidney stones. Therefore, Tables 1 and 2 summarize the molecules reported in the literature, the methods used, the animal models, and the main findings of each study.

\subsection{In Vitro Investigations}

Several researchers have reported, in vitro, the effect of catechin, resveratrol, epicatechin, hesperidin, hesperitin, and quercetin on the prevention of urolithiasis formation, using crystallization processes, artificial urine, and crystal development in cellular assays [10-12,16,18-24].

\subsubsection{Quercetin}

Park et al. [20] tested, in vitro, the effect of quercetin at different concentrations $(0$, 25, 50, and $100 \mu \mathrm{M}$ ) on Madin-Darby canine kidney (MDCK) cells induced by sodium oxalate. Quercetin (at $100 \mu \mathrm{M})$ significantly inhibited the decrease in the number of MDCK cells (between $70 \%$ and $80 \%$ of cell survival fraction at a concentration of $100 \mu \mathrm{M}$ ). Furthermore, lipid peroxidation was evaluated by monitoring malondialdehyde (MDA) production by oxalate at $1 \mathrm{mM}$. MDA production decreased significantly after 120 and $240 \mathrm{~min}$ of treatment with quercetin (at $100 \mu \mathrm{M}$ ) compared to cells exposed to sodium oxalate $(0.60 \mathrm{nmol} / \mathrm{mg}$ vs. $0.85 \mathrm{nmol} / \mathrm{mg}$ and $0.36 \mathrm{nmol} / \mathrm{mg}$ vs. $0.52 \mathrm{nmol} / \mathrm{mg}$, respectively). In addition, the activity of catalase was restored. Moreover, less than $200 \mu \mathrm{M}$ of quercetin showed no toxic effect on MDCK cells. The authors of this report revealed that quercetin decreases the oxidative injury of oxalate through the antioxidant pathway [20]. 
<smiles>[R]c1cc(-c2oc3cc(O)cc(O)c3c(=O)c2[R])ccc1O</smiles><smiles>Oc1ccc(/C=C/c2cc(O)cc(O)c2)cc1</smiles>

1: $\mathrm{R}_{1}=\mathrm{OH}, \mathrm{R}_{2}=\mathrm{OH}:$ Quercetin

2: $\mathrm{R}_{1}=\mathrm{H}, \mathrm{R}_{2}=\mathrm{H}$ : Apigenin<smiles>Oc1cc(O)c2c(c1)O[C@H](c1ccc(O)c(O)c1)C(O)C2</smiles><smiles>Oc1cc(O)c2c(c1)O[C@H](c1ccc(O)c(O)c1)[C@H](O)C2</smiles>

4: Catechin<smiles>CC1[C@H](C)C(Oc2c(-c3ccc(O)c(O)c3)oc3cc(O)cc(O)c3c2=O)O[C@H](C)[C@H]1C</smiles>

6: Hyperoside<smiles>COc1cc(/C=C/C(=O)CC(=O)/C=C/c2ccc(O)c(OC)c2)ccc1O</smiles>

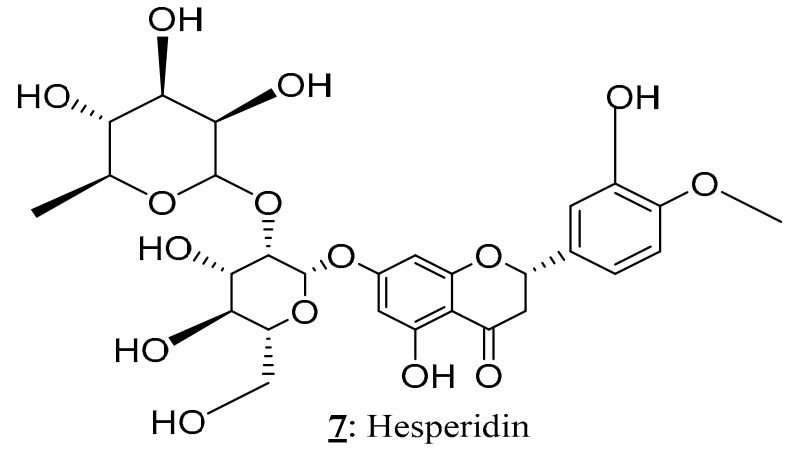

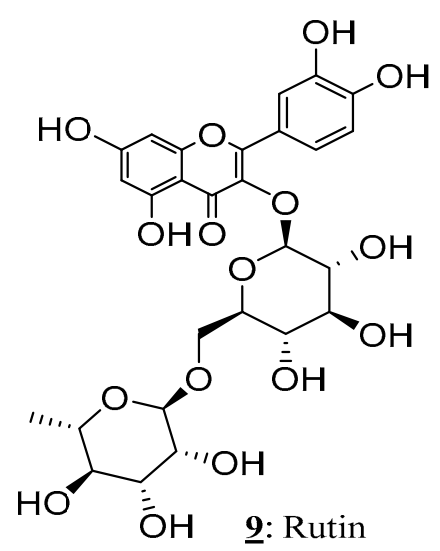

Figure 1. Structures of flavonoids and stilbenes with litholitic effects. 
Table 1. Anti-urolithiasis effects of flavonoids.

\begin{tabular}{|c|c|c|c|}
\hline Compounds & Methods & Key Results & References \\
\hline Apigenin & $\begin{array}{c}\text { Hyperoxaluria induced by ethylene glycol } \\
(0.75 \%) \text { and ammonium chloride }(2 \%) \text { in } \\
\text { rats for } 1 \text { week } \\
\text { Doses: } 1.2,2.4 \text {, and } 4.8 \mathrm{mg} / \mathrm{kg} \mathrm{b.w}\end{array}$ & $\begin{array}{c}\text { Decreased calcium levels in kidneys } \\
\text { Improved renal function } \\
\text { Decomposition of kidney stones } \\
\text { Increased urine calcium levels with increasing dose }\end{array}$ & [9] \\
\hline \multirow{2}{*}{ Catechin } & $\begin{array}{l}\text { In vitro and in vivo crystallization induced by } \\
\text { melamine-cyanuric acid mixture } \\
\text { Doses: } 2.5 \text { and } 10 \mathrm{mg} / \mathrm{kg} \text { b.w for } 28 \text { days }\end{array}$ & $\begin{array}{c}\text { Reduced the overall number of crystals in vitro } \\
\text { Suppressed MCM-induced protein expression } \\
\text { Decreased renal malondialdehyde (MDA) and urinary } \\
\text { 8-isoprostane (8-IP) } \\
\text { Improved the levels of antioxidant enzymes } \\
\text { Reduced the levels of renal crystals }\end{array}$ & [10] \\
\hline & $\begin{array}{c}\text { In vitro: crystallization induced by calcium } \\
\text { oxalate monohydrate in NRK-52E cells } \\
\text { In vivo: hyperoxaluria induced by } \\
\text { ethylene glycol } \\
\text { Doses: } 2.5 \text { and } 10 \mathrm{mg} / \mathrm{kg} / \text { day for } 14 \text { days }\end{array}$ & $\begin{array}{c}\text { Prevented the mitochondrial membrane } \\
\text { Prevented the expression of SOD, } 4 \text {-HNE, cytochrome c, } \\
\text { and cleaved caspase } 3 \\
\text { Decreased the expression of superoxide dismutase, } \\
\text { malondialdehyde, OPN, and 8-OHdG in rats } \\
\text { Prevented the EG-induced mitochondrial collapse in rats }\end{array}$ & [11] \\
\hline (-)-Epicatechin & $\begin{array}{c}\text { In vitro struvite crystallization in the solution of } \\
\text { artificial urine } \\
\text { Spectrophotometric measurements and } \\
\text { microscopic observations } \\
\text { Doses: } 125,250,500 \text {, and } 1000 \mu \mathrm{g} / \mathrm{mL}\end{array}$ & $\begin{array}{c}\text { Accelerated struvite nucleation } \\
\text { Increased the mass of struvite } \\
\text { Induced a change in color of urine } \\
\text { Reduced the levels of MgCit-, MgHCit, and } \mathrm{MgC}_{2} \mathrm{O}_{4} \\
\text { complexes formed in artificial urine }\end{array}$ & [12] \\
\hline \multirow[b]{2}{*}{ Rutin } & $\begin{array}{l}\text { Ethylene-glycol }(0.75 \%) \text { - and ammonium } \\
\text { (1\%)-induced CaOx urolithiasis in rats } \\
\text { Dose: } 20 \mathrm{mg} / \mathrm{kg} \text { b.w for } 28 \text { days }\end{array}$ & $\begin{array}{l}\text { Restored the levels of calcium and oxalate to near normal } \\
\text { Prevented lipid peroxidation } \\
\text { Decreased tissue damage and the levels of CaOx in } \\
\text { kidneys as compared to calculi-induced animals }\end{array}$ & [15] \\
\hline & $\begin{array}{c}\text { Ethylene-glycol }(0.75 \%) \text { - and ammonium } \\
\text { (1\%)-induced CaOx urolithiasis in rat daily } \\
\text { for } 28 \text { days } \\
\text { Dose: } 20 \mathrm{mg} / \mathrm{kg} \text { b.w }\end{array}$ & $\begin{array}{c}\text { Prevented increase in urine volume } \\
\text { Prevented increase in and restored the calcium and } \\
\text { oxalate to near normal } \\
\text { Reduced lipid peroxidation } \\
\text { Induced minimal kidney damage and histological } \\
\text { changes compared to the kidneys of } \\
\text { calculi-induced animals } \\
\text { Decreased the levels of } \mathrm{CaOx}\end{array}$ & [21] \\
\hline
\end{tabular}

Fifty millilitres of calcium chloride, $50 \mathrm{~mL}$ of sodium oxalate, and $50 \mathrm{~mL}$ of hesperidin solution $(1 \mathrm{~g} / \mathrm{L})$

Promoted the nucleation of crystal deposits Increased the levels of $\mathrm{CaOx}$ crystals and reduced their Calculated the inhibition rate size Inhibited $\mathrm{CaOx}$ crystal aggregation

Hesperidin Fifty millilitres of calcium chloride, $50 \mathrm{~mL}$ of sodium oxalate, and $50 \mathrm{~mL}$ of hesperitin solution $(1 \mathrm{~g} / \mathrm{L})$

Promoted the nucleation of crystal deposits

Increased the levels of crystal deposits and reduced their size Inhibited $\mathrm{CaOx}$ crystal aggregation

Calculated the inhibition rate

\begin{tabular}{|c|c|c|c|}
\hline $\begin{array}{l}\text { Hyperoside } \\
\text { and quercetin } \\
\text { (ratio 1:1) }\end{array}$ & $\begin{array}{l}\text { Ethylene-glycol }(0.5 \%) \text { - and vitamin-D3 } \\
(0.5 \mu \mathrm{mol}) \text {-fed rats } \\
\text { Hyperoside and quercetin (1:1) at } 20 \mathrm{mg} / \mathrm{kg} \text { b.w } \\
\text { daily for } 3 \text { weeks }\end{array}$ & $\begin{array}{l}\text { Decreased the number of crystal deposits } \\
\text { Increased significantly the SOD and catalase levels }\end{array}$ & [19] \\
\hline \multirow{3}{*}{ Quercetin } & $\begin{array}{l}\text { In vitro: renal tubular cell injury induced by } \\
\text { oxalate (MDCK cells) at doses } 0,25,50 \text {, and } \\
\qquad 100 \mu \mathrm{M} \\
\text { In vivo: sodium oxalate ( } 3 \% \text { ) induced urinary } \\
\text { crystal deposit formation for } 4 \text { weeks } \\
\text { Quercetin at } 10 \mathrm{mg} / \mathrm{kg} \text { daily for } 4 \text { weeks }\end{array}$ & $\begin{array}{c}\text { Increased the cell viability and prevented } \\
\text { lipid peroxidation } \\
\text { Decreased malondialdehyde levels } \\
\text { Increased catalase and superoxide dismutase activity } \\
\text { Decreased significantly the number of crystals in kidneys }\end{array}$ & [20] \\
\hline & $\begin{array}{l}\text { Hyperoxaluria induced by potassium } \\
\text { oxalate diet } \\
\text { Quercetin at } 10 \mathrm{mg} / \mathrm{kg} \text { daily from } 15 \text { to } 28 \text { days }\end{array}$ & $\begin{array}{c}\text { Altered the increased lipid peroxidation and antioxidant } \\
\text { depletion as compared with rats fed with KOx } \\
\text { Reduced CaOx aggregation in urine and kidneys } \\
\text { Altered the expression of } \mathrm{CaOx} \text { modulator genes and } \\
\text { antioxidant genes (GPx and SOD) }\end{array}$ & [23] \\
\hline & $\begin{array}{c}\text { Nephrolithiasis induced by ethylene } \\
\text { glycol ( } 0.75 \%) \\
\text { Dose: } 2 \mathrm{mg} / \mathrm{kg} \text { daily for } 28 \text { days }\end{array}$ & $\begin{array}{c}\text { Increased urine volume } \\
\text { Decreased the size of calculi } \\
\text { Enhanced the excretion of calcium, oxalate, and } \\
\text { phosphate, and increased the levels of magnesium } \\
\text { Reduced the levels of BUN and creatinine }\end{array}$ & [24] \\
\hline
\end{tabular}


Table 2. Stilbenes.

\begin{tabular}{|c|c|c|c|}
\hline Compounds & Methods & Key Results & References \\
\hline \multirow{5}{*}{ Curcumin } & $\begin{array}{l}\text { Ethylene-glycol }(0.75 \%) \text { - and vitamin-D3 } \\
(0.5 \mu \mathrm{g} / \mathrm{kg}) \text {-induced nephrolithiasis in rats } \\
\text { Dose: } 100 \mathrm{mg} / \mathrm{kg} / \text { day, p.o for } 28 \text { days }\end{array}$ & $\begin{array}{c}\text { Improved kidney function } \\
\text { Reduced the elevated oxidative stress } \\
\text { Increased the activity of the antioxidant enzymes } \\
\text { Decreased urinary oxalate level and renal deposition } \\
\text { of CaOx }\end{array}$ & [13] \\
\hline & $\begin{array}{c}\text { Urolithiasis induced by ethylene glycol (1\%) and } \\
\text { ammonium chloride }(1 \%) \\
\text { Dose: } 200 \mathrm{mg} / \mathrm{kg} \text { for } 28 \text { days }\end{array}$ & $\begin{array}{l}\text { Prevented changes in urinary levels of calcium, oxalate, } \\
\text { and phosphate } \\
\text { Decreased significantly the levels of calcium and oxalate } \\
\text { and the number of } \mathrm{CaOx} \text { crystals in the kidney tissue }\end{array}$ & [14] \\
\hline & $\begin{array}{c}\text { Glyoxylate }(100 \mathrm{mg} / \mathrm{kg}) \text {-induced } \mathrm{CaOx} \text { deposition } \\
\text { Doses: } 50 \text { or } 100 \mathrm{mg} / \mathrm{kg} \text { b.w for } 14 \text { days }\end{array}$ & $\begin{array}{c}\text { Reduced glyoxylate-induced CaOx deposition } \\
\text { Decreased MDA levels } \\
\text { Elevated the levels of antioxidant enzymes } \\
\text { Inhibited apoptosis and autophagy } \\
\text { Improved the expression of IL-6, MCP-1, OPN, CD44, } \\
\text { } \text {-SMA, collagen I, and collagen fibril deposition }\end{array}$ & [25] \\
\hline & $\begin{array}{c}\text { Ethylene-glycol }(0.75 \%) \text { - and-ammonium }(1 \%) \text {-induced } \\
\text { CaOx urolithiasis in rats } \\
\text { Dose: } 60 \mathrm{mg} / \mathrm{kg} \text { b.w for } 28 \text { days }\end{array}$ & $\begin{array}{l}\text { Restored the calcium and oxalate levels in urine and } \\
\text { kidney tissue to near normal } \\
\text { Prevented lipid peroxidation } \\
\text { Induced minimum tissue damage and a small number of } \\
\text { CaOx deposits in kidneys as compared to } \\
\text { calculi-induced animals }\end{array}$ & [15] \\
\hline & $\begin{array}{c}\text { Ethylene-glycol }(0.75 \%) \text { - and-ammonium }(1 \%) \text {-induced } \\
\text { CaOx urolithiasis in rats daily for } 28 \text { days } \\
\text { Dose: } 60 \mathrm{mg} / \mathrm{kg} \text { b.w }\end{array}$ & $\begin{array}{c}\text { Prevented the increase in urine volume } \\
\text { Prevented the increase in and restored the calcium and } \\
\text { oxalate levels in urine and kidney tissue } \\
\text { Reduced lipid peroxidation } \\
\text { Induced minimal kidney damage and histological } \\
\text { changes compared to the kidneys of } \\
\text { calculi-induced animals } \\
\text { Induced small and less abundant crystals }\end{array}$ & [15] \\
\hline \multirow[b]{2}{*}{ Resveratrol } & $\begin{array}{c}\text { Ethylene-glycol ( } 1 \%) \text {-induced hyperoxaluria-driven } \\
\text { nephrolithiasis/nephrocalcinosis in rats } \\
\text { Dose: } 10 \mathrm{mg} / \mathrm{kg} \text { for } 5 \text { weeks }\end{array}$ & $\begin{array}{c}\text { Decreased urinary oxalate levels } \\
\text { Decreased serum MDA levels } \\
\text { Generated histopathological changes via decreasing in } \\
\text { ethylene glycol } \\
\text { No significant inhibition of p38 MAPK and NFkB assays }\end{array}$ & [17] \\
\hline & $\begin{array}{c}\text { In vitro: human renal epithelial cells (HRCs) induced } \\
\text { by CaOx } \\
\text { Doses: } 40 \text { and } 80 \mu \mathrm{M} \\
\text { In vivo: ethylene-glycol }(0.8 \%) \text { - and-ammonium } \\
(1 \%) \text {-induced kidney stones } \\
\text { Doses: } 5 \text { and } 10 \mathrm{mg} / \mathrm{kg} \text { b.w for } 3 \text { weeks }\end{array}$ & $\begin{array}{c}\text { In vitro: Inhibited the oxalate-mediated migration } \\
\text { of HRCs } \\
\text { Suppressed the mRNA expression of NADPH oxidase, } \\
\text { MCP-1, and OPN } \\
\text { Down-regulated the expression of } \\
\text { MCP-1-related proteins } \\
\text { In vivo: Reduced oxalate-mediated production of ROS } \\
\text { and MDA } \\
\text { Enhanced the activities of antioxidant enzymes } \\
\text { Reduced the number of CaOx crystals in urine }\end{array}$ & [18] \\
\hline
\end{tabular}

\subsubsection{Resveratrol}

The in vitro assay of resveratrol (Figure 1) on human renal epithelial cells (HRCs), induced by calcium oxalate (CaOx), was carried out by Hyuk Hong et al. [18]. Resveratrol at 40 and $80 \mu \mathrm{M}$ suppressed the motility of oxalate-treated HRCs in a dose-dependent manner. Further, using the MTT colorimetric assay, this compound did not show significant cytotoxicity against HRCs up to $200 \mu \mathrm{M}$. There is evidence that oxalate promoted free radical production by activation of nicotinamide adenine dinucleotide phosphate hydrogen (NADPH) oxidase, monocyte chemoattractant protein-1 (MCP-1), and osteopontin (OPN) [18,21]. In a study by Hyuk Hong et al. [18], resveratrol suppressed mRNA expression of the NADPH oxidase transmembrane and cytosolic subunits, namely $\mathrm{p}^{2} 2^{\text {phox }}$, p47phox , MCP-1, and OPN [18]. Other mechanisms involved in the anti-urolithiasis activity of resveratrol are due to the modulation of TGF- $\beta$ signaling pathways. This bioactive compound down-regulated the expression of MCP-1-related proteins, including TGF- $\beta 1$, TGFR-1, or II, which are the primary sources of suppressed ROS generation via oxalate induced in renal epithelial cells [18]. 


\subsubsection{Catechin}

In another work carried out by Zhai et al. [11], catechin was evaluated in vitro on renal proximal tubular cell lines (NRK-52E) induced by calcium oxalate monohydrate (COM). Catechin prevented changes in mitochondrial membrane potential and normalized the expression of superoxide dismutase (SOD), 4-hydroxynonenal (4-HNE), cytochrome c, and cleaved caspase 3 in NRK-52E cells treated with COM. The effect of the same molecule has been investigated in vitro on the formation of crystals induced by a melamine-cyanuric acid mixture (MCM) (1:1) under various $\mathrm{pHs}(5.6,7.0$, and 8.1). From this experiment, catechin, in various concentrations $(0.5,1.0,2.0,5.0$, and $10.0 \mathrm{mM})$, reduced the overall number of crystals $(90.1 \%, 82.1 \%, 65.6 \%, 53.3 \%$, and $69.1 \%$, respectively) at a $\mathrm{pH}$ value of 5.6 with a non-cytotoxic level of $100 \mu \mathrm{M}$ [10]. In this study, the authors suggested that catechin is involved in the prevention of the formation of crystals which might grow into stable nuclei, and thus forms solid bonds.

The effect of (-)-epicatechin (Figure 1) at different concentrations (125, 250, 500, and $1000 \mu \mathrm{g} / \mathrm{mL}$ ) on struvite crystals was evaluated in artificial urine using spectrophotometer measurements and microscope observation [12]. The effect of (-)-epicatechin was observed in two stages of crystallization: nucleation and the growth of struvite crystals. Using (-)-epicatechin at $125 \mu \mathrm{g} / \mathrm{mL}$, the final value absorbance is more than $120 \%$, while for 250 and $500 \mu \mathrm{g} / \mathrm{mL}$, the final absorbance value was about $150 \%$ for both concentrations without reaching the state of saturation [12]. This elevation was due to the acceleration of struvite nucleation and growth. The increase in $\mathrm{pH}$ value caused an increase in the absorbance of artificial urine as well as a change in the color of this urine from transparent to yellow due to the oxidation of (-)-epicatechin. In addition, (-)-epicatechin reduced the concentration of $\mathrm{MgCit}-, \mathrm{MgHCit}$, and $\mathrm{MgC}_{2} \mathrm{O}_{4}$ complexes, which leads to an increase in the concentration of free $\mathrm{Mg}^{2+}$ ions in $\mathrm{pH}$ values from 1 to 8.5 [12].

\subsubsection{Hesperidin and Hesperitin}

Sekkoum et al. [16] investigated, in vitro, the effect of two bioflavonoids: hesperidin and hesperitin (from sweet orange), at different concentrations $(0.0625,0.125,0.25$, and $0.5 \mathrm{~g} / \mathrm{L}$ ), on $\mathrm{CaOx}$ crystallization using an infrared spectrometer and microscope observation. At $0.25 \mathrm{~g} / \mathrm{L}$, hesperidin and hesperitin presented a rate of inhibition value of $90.4 \%$ and $87.94 \%$, respectively. In addition, the chiral analyses of hesperidin and hesperitin showed two diastereomers (65:35) and two enantiomers (50:50), respectively. This variance influenced the inhibition factors. Furthermore, these two bioflavonoids promoted the nucleation of $\mathrm{CaOx}$ crystals while inhibiting the aggregation process [16].

\subsection{In Vivo Investigations}

The anti-lithiasis effect of rutin, apigenin, catechin, curcumin, resveratrol, and quercetin was reported by several investigators (Tables 1 and 2) using several animal models, as well as the oral administration of ethylene glycol (EG), EG with vitamin D3, EG with ammonium chloride, an oxalate rich diet, and MCM in rats [9-11,13-15,17-20,22-24].

\subsubsection{Rutin}

The nephrolithiasis effect of rutin was evaluated in EG-induced CaOx urolithiasis in rats $[15,22]$. At $20 \mathrm{mg} / \mathrm{kg}$ for 28 days, the calcium and oxalate levels in urine and kidney tissues were reduced compared to lithiasis rats $(0.35 \mathrm{mg} /$ day vs. $0.86 \mathrm{mg} /$ day and $11.70 \mathrm{mg} /$ day vs. $21.26 \mathrm{mg} /$ day, respectively in urine, and $0.18 \mathrm{mg} / \mathrm{g}$ vs. $0.27 \mathrm{mg} / \mathrm{g}$ and $7.73 \mathrm{mg} / \mathrm{g}$ vs. $11.46 \mathrm{mg} / \mathrm{g}$, respectively in kidneys). Rutin prevented lipid peroxidation of kidney tissue $(66.39 \%)$. Rutin reduced the number of CaOx deposits, so there were less in kidneys compared to those in urolithiasis rats ( 7.50 vs. 34.17 , respectively). In the same year, Ghodasara and colleagues studied the effect of rutin at the same concentration using the same experimental approach. The same results were obtained by this phytomolecule. Authors from this research suggested that rutin increased the bioavailability of nitric oxide, 
(NO) which activates cGMP $\left(3^{\prime}, 5^{\prime}\right.$ cyclic guanosine monophosphate) and thereby controls the increase in intracellular calcium levels [15].

\subsubsection{Catechin}

The urolithiasis effect of catechin at 2.5 and $10 \mathrm{mg} / \mathrm{kg} /$ day was evaluated in $\mathrm{CaOx}$ Sprague Dawley rats induced by $1 \%$ ethylene glycol [11]. In this study, catechin at $10 \mathrm{mg} / \mathrm{kg} /$ day enhanced significantly urine volume and urine oxalate compared to the EG group $(27.05 \pm 7.5 \mathrm{~mL}$ vs. $16.05 \pm 7.5 \mathrm{~mL}$ and $13.58 \pm 1.3 \mathrm{mg} /$ day vs. $14.53 \pm 2.4 \mathrm{mg} /$ day, respectively) whereas no significant difference was observed in serum creatinine and calcium levels. Furthermore, this compound decreased the expression of SOD, OPN, MDA, and 8-OHdG using immunohistochemical staining and prevented EG-induced mitochondrial collapse in rats [11]. In this study, the authors suggested that this effect was achieved by mitigating oxidative damage and affecting the regulation of renal tubular epithelial cell apoptosis in rats. Two years later, $\mathrm{Li}$ and colleagues investigated in vivo the effect of the same molecule in rats fed orally with a melamine-cyanuric acid mixture $(400 \mathrm{mg} / \mathrm{kg})$. Catechin feeding at a dose of $10 \mathrm{mg} / \mathrm{kg} /$ day enhanced significantly SOD to normal levels and decreased renal MDA and urinary 8-isoprostane (8-IP) to normal contents. Histological examination showed a significant reduction in crystal deposition in the cortices, medullae, and papillae of the rat renal sections. The authors suggested that the mechanism of action of this compound acts by reducing the expression of OPN as well as that of phosphor-p38 [10].

\subsubsection{Curcumin}

Furthermore, several authors evaluated, in vivo, the effect of curcumin on $\mathrm{CaOx}$ urolithiasis in rats [2,13-15]. Curcumin at $100 \mathrm{mg} / \mathrm{kg} /$ day for 28 days improved renal function, reduced elevating oxidative stress, increased antioxidant enzyme activity, and decreased urinary oxalate levels as well as renal deposition of $\mathrm{CaOx}$ [13]. After one year, the same compound at $60 \mathrm{mg} / \mathrm{kg}$ for 28 days restored calcium and oxalate levels in urine and kidney tissue to near normal levels $(0.20 \mathrm{mg} /$ day vs. $0.17 \mathrm{mg} /$ day and $7.37 \mathrm{mg} /$ day vs. $4.10 \mathrm{mg} /$ day, respectively in urine, and $0.16 \mathrm{mg} / \mathrm{g}$ vs. $0.15 \mathrm{mg} / \mathrm{g}$ and $7.76 \mathrm{mg} / \mathrm{g}$ vs. $5.52 \mathrm{mg} / \mathrm{g}$, respectively in kidneys). The lipid peroxidation of kidney tissue was prevented $(21.59 \%)$. Using Pizzolato's method, the number of $\mathrm{CaOx}$ deposits was less in kidneys treated with curcumin compared to those in urolithiasis rats ( 9.00 vs. 34.17, respectively) [15]. These results corroborate the findings of [14,15], who found that after 28 days of treatment with curcuma at the doses of 60 and $200 \mathrm{mg} / \mathrm{kg} /$ day, respectively, the calcium and oxalate levels and the number of $\mathrm{CaOx}$ crystals in the kidney tissue were significantly decreased in calculogenic rats in curative treatment [15] and in both prophylactic and curative treatment [14]. Li et al. [25] showed that curcumin (at 50 and $100 \mathrm{mg} / \mathrm{kg}$ for 14 days) reduced significantly CaOx crystal deposition and attenuated the renal tissue damage with no significant difference between the curcumin $50 \mathrm{mg} / \mathrm{kg}$ and curcumin $100 \mathrm{mg} / \mathrm{kg}$ groups. Simultaneously, a significant increase in the levels of SOD, CAT, glutathione peroxidase (GPx), CR, and GSH, and a decrease in MDA, were observed in nephrolithiasis mouse kidneys treated with this molecule. Further, the high expression of OPN, CD44, and MCP-1, and IL- $6, \alpha-S M A$, collagen I, and collagen fibril deposition decreased with no dose-dependent manner [25]. The anti-nephrolithiasis effect of curcumin was mediated by activating the nuclear factor erythroid-2-related factor (Nrf2), HO-1, NQO1, and UGT expression, which led to the minimization of ROS formation and the attenuation of inflammation and renal fibrosis. Pawar and co-workers reported that curcumin acts through two mechanism pathways, via inhibiting oxalate synthesis and increasing the bioavailability of NO to sequester calcium through the cGMP pathway [15]. The improvement of renoprotective activity observed by curcumin in these works on various in vivo models could be attributed to a combination of several mechanisms of action involved in antioxidant, antiapoptotic, inhibition autophagy, anti-inflammatory, and anti-fibrotic activities $[13,15,25]$. 


\subsubsection{Resveratrol}

In other works, resveratrol at $5 \mathrm{mg} / \mathrm{kg}$ and $10 \mathrm{mg} / \mathrm{kg}$ was investigated for its litholytic effect on $\mathrm{CaOx}[17,18]$. After treatment with resveratrol, a significant reduction in ROS, serum MDA level, and the number of urine $\mathrm{CaOx}$ crystals has been reported and approved $[17,18]$. The formation of $\mathrm{CaOx}$ crystals was correlated with the expression of OPN and hyaluroran (HA), which was supported by previous evidence $[18,26,27]$. Resveratrol reduced the expression of HA in rats with EG-induced hyperoxaluria. Adding to their nephrolithiasis effect, Hyuk Hong and colleagues analyzed several antioxidant enzymes in kidneys by determining the effects of resveratrol against $\mathrm{CaOx}$ induced in rats by EG $(1 \%)$. After exposure to EG, the authors observed a significant attenuation of the levels of glutathione peroxidase, catalase, and SOD compared to the untreated group. The treatment with resveratrol enhanced the activities of these antioxidant enzymes in a dosedependent manner. Histological examination of renal tissue confirmed that resveratrol reduced mononuclear cell infiltration in the renal medulla and cortex layers congestion of glomerular vessels as well as in the lumen of the tubules, especially in the proximal tubules. However, this compound did not inhibit p38 MAPK and NFkB assays significantly [18].

\subsubsection{Quercetin}

Quercetin (Figure 1) is widely tested for its pharmacological effects in vivo [28-30]. However, few studies investigated its effects on nephrolithiasis animal models. The activity of quercetin was first studied by Park et al. [20]. In fact, they observed that the oral administration of quercetin at $10 \mathrm{mg} / \mathrm{kg}$ in lithiasis rats for 4 weeks reduced both MDA production and the number of crystals in kidneys, and significantly increased catalase and superoxide dismutase activity. The number of $\mathrm{CaOx}$ crystals in the quercetin group was significantly lower than in sodium oxalate group ( $2.5 \pm 1.7$ vs. $4.3 \pm 1.8$, respectively). In 2014 , the prophylactic effect of the same molecule combined with hyperoside (QH ratio 1:1) was investigated at $20 \mathrm{mg} / \mathrm{kg} /$ day in urolithiasis rats. After 21 days, they found that the treatment by gastric intubation increased significantly the superoxide dismutase and catalase levels and decreased significantly the number of crystals deposits [19]. The authors suggested three mechanisms of action involved in $\mathrm{QH}$ against nephrolithiasis, including the inhibition of crystal formation by increasing urine $\mathrm{pH}$, the anti-apoptotic effect, and the antioxidative effects. However, the exact mechanism of this bioactive compound remains unknown. After one year, the effect of quercetin in rats fed with a potassium-oxalate (KOx)-rich diet was studied by Gomathi et al. [23]. At $10 \mathrm{mg} / \mathrm{kg} /$ day, the urinary $\mathrm{pH}$ of quercetin-treated rats showed the same $\mathrm{pH}$ value as the control ( $6.92 \pm 0.12 \mathrm{vs} .7 .26 \pm 0.12 \mathrm{~mL} /$ day, respectively) while urinary volume was enhanced ( $8.6 \pm 0.89$ vs. $5.2 \pm 0.66 \mathrm{~mL} /$ day, respectively). In addition, uric acid and phosphate concentrations were significantly reduced in rats treated with quercetin compared to lithiasis rats $(0.75 \pm 0.09$ vs. $1.20 \pm 0.10 \mathrm{mg} /$ day and $6.52 \pm 0.35$ vs. $6.80 \pm 0.38 \mathrm{mg} /$ day). In addition, histopathological analysis revealed that this bioactive compound protected KOx-induced interstitial inflammation and high $\mathrm{CaOx}$ crystal deposition in lithiasis rats. Furthermore, Gomathi et al. [23] analyzed the gene expression of OPN, angiotensin-converting enzyme (ACE), and renin using real-time PCR with GADPH as a reference gene, and revealed that quercetin significantly reduced the expression of OPN, ACE, and renin compared to lithiasis rats while the expression of SOD and GPx mRNA was increased. The authors suggested that this protective activity was mediated by antioxidant activity. The high diffusion ability into the membranes and chelating action of the catechol group explain the activity of the free radicals of quercetin. After three years, Dinnimath et al. [24] evaluated the effect of quercetin, isolated from Aerva lanata L. (Belagavi Dist, Karnataka), at $2 \mathrm{mg} / \mathrm{kg} /$ day orally for 28 days on calculi formed by EG $(0.75 \%)$ in rats. The results showed a significant reduction in biochemical parameter levels in urinary samples (calcium, phosphate, and oxalate), and serum parameters (creatinine and BUN) in rats treated with quercetin, while the level of magnesium (the main kidney stone inhibitor) increased [24]. The latter prevents oxalate supersaturation by inhibiting 
their absorption. From these findings, the authors suggested that quercetin possessed an important anti-lithiasis effect due to the inhibition of the activity of oxalate oxidase enzyme.

In hyperoxaluria in rats developed by Stiani et al. [9], oral administration of EG $(0.75 \%)$ and ammonium chloride (2\%), apigenin (isolated from Celery, Apium graveolens L.) at 1.2, 2.4 , and $4.8 \mathrm{mg} / \mathrm{kg}$ reduced calcium levels in the kidney $(306.25,297.89$, and $187.66 \mathrm{ppm}$, respectively vs. normal control $187.00 \mathrm{ppm}$ ) and significantly improved the calcium level in urine (310.80, 520.82, and $544.61 \mathrm{ppm}$, respectively) [9]. According to the findings of this work, the authors suggested that apigenin acts as rutin by lowering NO, which inactivates cGMP and controls the increase in intracellular calcium levels. Therefore, this compound can be developed clinically as a litholytic drug.

\section{Litholytic Activity of Phenolic Acids}

Phenolic acids demonstrate several potent pharmacological effects, including antioxidant, antimicrobial, anticancer, antiviral, anti-inflammatory, antimutagenic, antirheumatic, antipyretic, antiseptic, anthelmintic, neuroprotective, and hepatoprotective activities [31]. However, knowledge of the anti-lithiasis effect of phenolic acids is still lacking. Here (Table 3), we discuss, in vitro and in vivo, four bioactive compounds of these aromatic acids as reported by several studies [32-36].

Table 3. Anti-urolithiasis effects of phenolic acids.

\begin{tabular}{|c|c|c|c|}
\hline Compounds & Methods & Key Results & References \\
\hline \multirow[t]{2}{*}{ Caffeic acid } & $\begin{array}{l}\text { Ethylene glycol induced kidney stones in rats } \\
\text { Doses: } 20 \text { and } 40 \mathrm{mg} / \mathrm{kg} \text { for } 8 \text { weeks }\end{array}$ & $\begin{array}{l}\text { Regulated the altered biochemical parameters } \\
\text { Reduced CaOx deposits in kidneys } \\
\text { Down-regulated the osteopontin gene } \\
\text { Up-regulated the prothrombin fragment 1, } \\
\text { Tamm-Horsfall, and bikunin genes }\end{array}$ & {$[33]$} \\
\hline & $\begin{array}{c}\mathrm{CaOx} \text { crystallization in synthetic urine } \\
\text { Forty microlitres of sodium oxalate } 0.1 \mathrm{M} \text { was } \\
\text { added per milliliter of urine } \\
\text { Doses: } 0.03,0.1 \text {, and } 0.3 \mathrm{mg} / \mathrm{mL}\end{array}$ & $\begin{array}{l}\text { Decreased the number of monohydrate and dihydrate } \\
\text { forms of crystals }\end{array}$ & {$[36]$} \\
\hline Ferulic acid & $\begin{array}{c}\text { Ethylene-glycol }(0.75 \%) \text {-induced renal calculus } \\
\text { in experimental rats } \\
\text { Doses: } 40 \text { and } 80 \mathrm{mg} / \mathrm{kg} \text { daily for } 28 \text { days }\end{array}$ & $\begin{array}{c}\text { Regulated the altered biochemical parameters } \\
\text { Inhibited oxidative stress } \\
\text { Increased GSH, SOD, GPx, and CAT levels } \\
\text { Decreased lipid peroxidation (LPO) } \\
\text { Decreased serum and urine levels of stone and } \\
\text { renal markers }\end{array}$ & {$[34]$} \\
\hline $\begin{array}{l}\text { Gallic acid and } \\
\text { chitosan }\end{array}$ & $\begin{array}{l}\text { Measurement of crystallization of calcium } \\
\text { oxalate by spectrophotometry in artificial urine } \\
\text { Dose: } 10 \mathrm{mg} \text { of gallic acid per g of chitosan }\end{array}$ & Decreased the formation of $\mathrm{CaOx}$ crystals & {$[35]$} \\
\hline \multirow[t]{2}{*}{ Rosmarinic acid } & $\begin{array}{l}\text { Ethylene-glycol-induced kidney stones in rats } \\
\text { Doses: } 50 \text { and } 100 \mathrm{mg} / \mathrm{kg}\end{array}$ & $\begin{array}{l}\text { Decreased urinary excretions of creatinine, uric acid, } \\
\qquad \mathrm{Ca}^{2+} \text {, and oxalic acid } \\
\text { Decreased the concentration of creatinine, uric acid, } \\
\text { and urea } \\
\text { Decreased the contents of renal tissue oxalic acid and } \\
\text { calcium in kidneys } \\
\text { Decreased the calcium oxalate deposits in the kidneys } \\
\text { and the pathological change degrees }\end{array}$ & {$[32]$} \\
\hline & $\begin{array}{c}\text { CaOx crystallization in synthetic urine } \\
\text { Forty microlitres of sodium oxalate } 0.1 \mathrm{M} \text { was } \\
\text { added per milliliter of urine } \\
\text { Doses: } 0.03,0.1 \text {, and } 0.3 \mathrm{mg} / \mathrm{mL}\end{array}$ & $\begin{array}{l}\text { Decreased the number of monohydrate and dihydrate } \\
\text { forms of crystals in urine }\end{array}$ & {$[36]$} \\
\hline
\end{tabular}

\subsection{In Vitro Investigations}

\subsubsection{Chitosan}

Chitosan, a natural polymer of marine origin [37], has numerous biomedical applications $[38,39]$. However, chitosan tends to accumulate in renal tissue and promotes increased calcium excretion as well as the formation of COM crystals $[35,40]$. In this context, recent research conducted by Queiroz et al. [35] evaluated, in vitro, the effect of chitosan conju- 
gated to gallic acid for its litholytic activity on $\mathrm{CaOx}$. The effect of gallic acid-chitosan on the formation of crystalline $\mathrm{CaOx}$ was investigated, in particular on the nucleation, growth, and aggregation phases. Using gallic acid-chitosan, two distinct phases were observed (nucleation/growth and aggregation), while a phase with a 10-fold increase in absorbance value was reported using chitosan alone (nucleation/growth) [35]. Successively, the polarization microscopy, at the end of the experiment, revealed a decrease in the number of crystals in the gallic acid-chitosan assay compared to chitosan alone with a dominance of COM (9.25 \pm 4.04 crystals per field vs. $94.5 \pm 14.35$ crystals per field, respectively). This effect was related to the amine group of gallic acid that binds to chitosan, leading to a decrease in the charge of this biopolymer and consequently to a small interaction with the crystals [35]. Thus, the conjugate gallic acid-chitosan can be used as a chitosan substitute. However, further in vivo assays should be conducted.

\subsubsection{Caffeic Acid}

Caffeic acid (Figure 2), naturally synthesized by all plant species, is promising for health promotion, not only for its anti-inflammatory, antioxidant, and anticarcinogenic activities [41], but also for its potential anti-urolithiatic effect [36]. This phenolic acid at 0.03 , 0.1 , and $0.3 \mathrm{mg} / \mathrm{mL}$ was evaluated, in vitro, for its effect on CaOx crystallization in synthetic urine. This compound decreased the number of both $\mathrm{CaOx}$ monohydrated and dehydrated forms of crystals. The effect of rosmarinic acid at $0.03,0.1$, and $0.3 \mathrm{mg} / \mathrm{mL}$ showed the same result [36]. However, the mechanism of action of caffeic acid and rosmarinic acid remains unknown.<smiles>O=C(O)C=Cc1ccc(O)c(O)c1</smiles>

Figure 2. Chemical structure of caffeic acid.

\subsection{In Vivo Investigations}

\subsubsection{Rosmarinic Acid}

The anti-urolithiatic effect of rosmarinic acid (Figure 3) on EG-induced hyperoxaluria in rats was evaluated by You-xia et al. [32]. The results showed that this molecule at doses of 50 and $100 \mathrm{mg} / \mathrm{kg}$ exhibited a potent in vivo decrease in urinary parameters (creatinine, uric acid, $\mathrm{Ca}^{2+}$, and oxalic acid levels), serum parameters (creatinine, uric acid, and blood urea nitrogen levels), and kidney parameters (oxalic acid and calcium levels) [32].

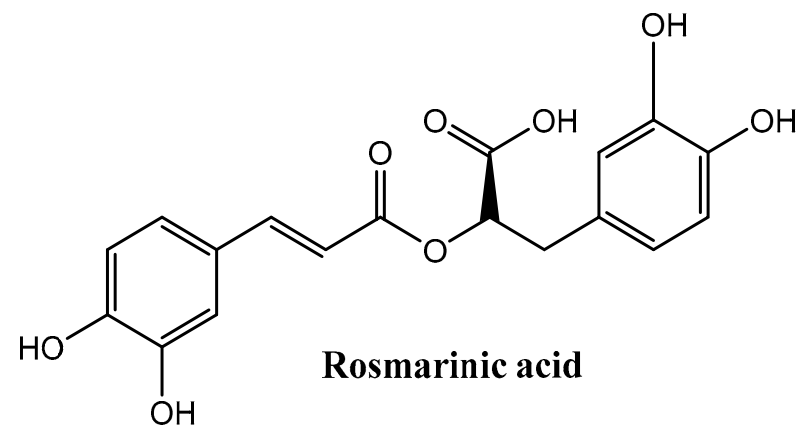

Figure 3. Chemical structure of rosmarinic acid. 


\subsubsection{Caffeic Acid}

In animals fed with EG (0.75\%) and ammonium chloride (1\%), caffeic acid (Figure 2) at doses of 20 and $40 \mathrm{mg} / \mathrm{kg}$, investigated for its preventive and curative treatment, regulated the alteration of biochemical parameters and reduced $\mathrm{CaOx}$ deposits in the kidneys [33]. In the kidneys of hyperoxaluria rats, OPN (disease indicator protein) [27] covered the surfaces of epithelial cells and promoted the adhesion and aggregation of $\mathrm{CaOx}$ crystals [42]. In the study of Yasir et al. [33], caffeic acid down-regulated the OPN gene, which inhibited the process of kidney stone formation. Furthermore, this molecule up-regulated prothrombin fragment 1, Tamm-Horsfall, and bikunin genes. These protect against crystallization, aggregation, and adhesion of $\mathrm{CaOx}$ crystals in epithelial cells.

\subsubsection{Ferulic Acid}

The anti-nephrolithiasis effect of ferulic acid (Figure 4) was evaluated using ethyleneglycol-induced kidney stones in a rat model. The oral administration of ferulic acid at 40 and $80 \mathrm{mg} / \mathrm{kg}$ by Zhao et al. [34] showed significant regulation of biochemical parameters in serum and kidneys in a dose-dependent manner. At $80 \mathrm{mg} / \mathrm{kg}$, aspartate aminotransferase (AST), alkaline phosphatase (ALP), gamma glutamyl transferase (GGT), alanine aminotransferase (ALT), and lactate dehydrogenase (LDH) in the kidneys were markedly mitigated by ferulic acid to near normal $(5.12 \pm 0.38 \mathrm{U} / \mathrm{mg}$ protein, $31.21 \pm 1.13 \mathrm{U} / \mathrm{mg}$ protein, $28.36 \pm 0.98 \mathrm{U} / \mathrm{mg}$ protein, $24.96 \pm 0.89 \mathrm{U} / \mathrm{mg}$ protein, and $9.36 \pm 0.28 \mathrm{U} / \mathrm{mg}$ protein, respectively) [34]. Simultaneously, this bioactive molecule significantly decreased renal markers (calcium, oxalate, uric acid, magnesium, urea, creatinine, and total protein) in urine and plasma compared to the EG-treated group. Hyperoxaluria reduced markedly the antioxidant enzymes (GSH, SOD, GPx, and CAT levels) due to a collapse of the antioxidant defense system, which leads to the formation of kidney stones. Ferulic acid at $80 \mathrm{mg} / \mathrm{kg}$ has the ability to increase the levels of these antioxidant enzymes compared to the EG group $(1.20 \mathrm{vs} .1 .02 \mathrm{U} / \mathrm{mg}$ protein, $1.41 \mathrm{vs} .0 .94 \mathrm{U} / \mathrm{mg}$ protein, $0.72 \mathrm{vs} .0 .42 \mathrm{U} / \mathrm{mg}$ protein, and 1.20 vs. $0.96 \mathrm{U} / \mathrm{mg}$ protein, respectively), while decreasing $\mathrm{LPO}(0.73 \mathrm{vs} .0 .94 \mathrm{U} / \mathrm{mg}$ protein), thereby regulating the ROS [34]. In addition, histopathological analysis revealed that ferulic acid treatment significantly protected EG-induced tissue damage in a dosedependent manner. However, further studies elucidating the mechanism involved in anti-lithiasis by ferulic acid should be conducted.<smiles>CCCCCCCCCCC=Cc1cc(O)c(O)c(OC)c1</smiles>

Figure 4. Chemical structure of ferulic acid.

\section{Litholytic Activity of Other Compounds}

Several studies have evaluated, in vitro and in vivo, the anti-lithiasis activity of other classes of bioactive compounds (terpenoids, furanochromes, carotenoids, alkaloids, quinones, and fatty acids). Therefore, the molecules, the method used, the animal models, and the main findings of each piece of research are depicted in Table 4. 
Table 4. Anti-urolithiasis effects of other compounds.

\section{Compounds}

Taraxasterol ammonium chloride

Doses: 2, 4, and $8 \mathrm{mg} / \mathrm{kg}$ for 33 days
Nephrolithiasis induced by ethylene glycol and

\section{Key Results}

References

Reduced the levels of calcium, AST, ALT, and LDH

Reduced magnesium and oxalate levels in urine

Reduced number of crystal deposits, score of crystal deposits, score of

histopathological damages, and score of inflammation in kidney sections

Elevated urine $\mathrm{pH}$, calcium, and citrate

Increased serum levels of magnesium and albumin, SOD, and CAT

$\mathrm{CaOx}$ crystallization in synthetic urine

Doses: $2.5,5,7.5$, and $12.5 \mu \mathrm{g} / \mathrm{mL}$

Nephrolithiasis induced by ethylene glycol Dose: $2 \mathrm{mg} / \mathrm{kg}$ b.w for 28 days

Urolithiasis induced by the insertion of a piece of zinc (10-12 mg)

followed by $2 \%$ ammonium oxalate

Betulin

(terpenoids)
Dose: $35 \mathrm{mg}$ per kg-1 b.w per day, p.o for 15 days

Crystallization assay and microscopic study:

$50 \mathrm{~mL}$ of sodium oxalate solution added to normal urine samples

Doses: 5 to $160 \mu \mathrm{g}$

Nucleation assay

Aggregation assay
Inhibited the nucleation of crystals (26-64\%)

Decreased significantly the number of $\mathrm{CaOx}$ crystals

Decreased the $\mathrm{CaC}_{2} \mathrm{O}_{4}$ dihydrate crystals diameter

\section{Increased urine volume}

Reduced the size of $\mathrm{CaOx}$ crystals

Decreased the level of calcium oxalate and phosphate

Increased the level of magnesium

Reduced the level of BUN and creatinine

Restored the concentration of antioxidant enzymes

Reduced the level of oxalate supersaturation in the tissues

Inhibited the crystallization of $\mathrm{CaOX}$ in urine

Inhibited the growth of $\mathrm{CaOX}$ crystals

Inhibited $\mathrm{CaOX}$ crystal aggregation and the agglomeration of particles 
Table 4. Cont.

\begin{tabular}{|c|c|c|c|}
\hline Compounds & Methods & Key Results & References \\
\hline \multirow{4}{*}{$\begin{array}{l}\text { Lupeol } \\
\text { (terpenoids) }\end{array}$} & $\begin{array}{c}\text { Urolithiasis induced by the insertion of a piece of zinc }(10-12 \mathrm{mg}) \\
\text { followed by } 2 \% \text { ammonium oxalate } \\
\text { Dose: } 35 \mathrm{mg} / \mathrm{kg} \text { b.w per day, p.o for } 15 \text { days }\end{array}$ & $\begin{array}{l}\text { Restored the concentration of antioxidant enzymes } \\
\text { Reduced the level of oxalate in the tissues }\end{array}$ & [52] \\
\hline & $\begin{array}{l}\text { Hyperoxaluria induced by feeding a pyridoxine-deficient diet } \\
\text { (PDD) for } 21 \text { days } \\
\text { Dose: } 35 \mathrm{mg} / \mathrm{kg} \text { b.w } / \mathrm{d} / \mathrm{rat}\end{array}$ & $\begin{array}{c}\text { Decreased the levels of oxalate } \\
\text { Reduced the levels of calcium } \\
\text { Pronounced change in magnesium and GAG excretion } \\
\text { Increased creatinine excretion } \\
\text { Decreased level of protein in the urine } \\
\text { Normalized LDH excretion } \\
\text { Reduced GGT excretion to near normal levels } \\
\text { Reduced the lysosomal marker enzymes }\end{array}$ & [53] \\
\hline & $\begin{array}{l}\text { Nephrolithiasis induced by implantation of glass bead } \\
\text { (15-18 mg) } \\
\text { Doses: } 10,25 \text {, or } 50 \mathrm{mg} / \mathrm{kg} \text { daily for } 16 \text { weeks }\end{array}$ & $\begin{array}{l}\text { Produced a significant reduction in the weight of the urolith formed } \\
\text { Reduced the phosphates, calcium, and magnesium levels } \\
\text { Reduced the deposition of phosphate and calcium } \\
\text { Normalized the erythrocytes, pus cells, and calcium oxalate crystals } \\
\text { Decreased urinary calcium, phosphate, and oxalate levels } \\
\text { Restored the total leucocyte count }\end{array}$ & [50] \\
\hline & $\begin{array}{l}\text { Hyperoxaluric induced by gastric intubation of } 2 \% \text { solution of } \\
\text { ammonium oxalate } \\
\text { Dose: } 25 \mathrm{mg} / \mathrm{kg} \mathrm{b.w} / \text { day for } 15 \text { days }\end{array}$ & $\begin{array}{c}\text { Decreased significantly the levels of oxalate in kidneys } \\
\text { Reduced the damage of renal tubular } \\
\text { Decreased levels of the urinary marker enzymes (ALT, LDH, inorganic } \\
\text { pyrophosphatase, AST, gamma glutamyl transferase, } \beta \text {-glucuronidase, and } \\
\text { N-acetyl } \beta \text {-D glucosaminidase). }\end{array}$ & [51] \\
\hline $\begin{array}{l}\text { Khellin } \\
\text { (furanochrome) }\end{array}$ & $\begin{array}{c}\text { Ethylene-glycol (0.75\%)- and (1\%)-ammonium-chloride-induced } \\
\text { CaOx renal stone formation } \\
\text { Dose: } 5 \text { and } 10 \mathrm{mg} / \mathrm{kg} \text { for } 14 \text { days by gavage }\end{array}$ & $\begin{array}{l}\text { Decreased the incidence of calcium oxalate }(\mathrm{CaOx}) \text { crystal deposition } \\
\text { No effect on urinary citrate or oxalate excretion }\end{array}$ & [57] \\
\hline $\begin{array}{l}\text { Visnagin } \\
\text { (furanochrome) }\end{array}$ & $\begin{array}{c}\text { Ethylene-glycol }(0.75 \%) \text { - and } \\
\text { (1\%)-ammonium-chloride-induced nephrolithiasis } \\
\text { Doses: } 5 \text { and } 10 \mathrm{mg} / \mathrm{kg} \text { for } 14 \text { days by gavage }\end{array}$ & $\begin{array}{l}\text { Decreased the incidence of calcium oxalate }(\mathrm{CaOx}) \text { crystal deposition } \\
\text { No effect on urinary citrate or oxalate excretion }\end{array}$ & [57] \\
\hline
\end{tabular}


Table 4. Cont.

\begin{tabular}{|c|c|c|c|}
\hline Compounds & Methods & Key Results & References \\
\hline $\begin{array}{l}\text { Crocin } \\
\text { (carotenoids) }\end{array}$ & $\begin{array}{l}\text { Ethylene-glycol (EG)-induced nephrolithiasis in rats } \\
\text { Doses: } 10,20 \text {, and } 40 \mathrm{mg} / \mathrm{kg} / \text { day, i.p. }\end{array}$ & $\begin{array}{c}\text { Decreased the levels of oxalate } \\
\text { Increased the levels of citrate and magnesium in urine } \\
\text { No significant effect on urine volume } \\
\text { Decreased the number of calcium deposits in the kidney } \\
\text { Decreased the levels of MDA } \\
\text { No significant alteration of urinary ionic parameters and crystal count in } \\
\text { curative treatment }\end{array}$ & [59] \\
\hline $\begin{array}{l}\text { Piperine } \\
\text { (alkaloids) }\end{array}$ & $\begin{array}{l}\text { In vitro: titrimetric method and aggregation assay } \\
\text { Doses: } 10 \text { and } 20 \mathrm{mg} / \mathrm{kg} \\
\text { In vivo: hyperoxaluria induced in rats } \\
\text { Doses: } 40 \text { and } 80 \mathrm{mg} / \mathrm{kg} \text { p.o }\end{array}$ & $\begin{array}{l}\text { Inhibited the crystallization } \\
\text { Ameliorated the serum parameters (calcium, urea, uric acid, and creatinine) } \\
\text { Ameliorated the levels of calcium and oxalate in urine }\end{array}$ & {$[48]$} \\
\hline $\begin{array}{l}\text { Berberine } \\
\text { (alkaloids) }\end{array}$ & $\begin{array}{l}\text { Nephrolithiasis induced by ethylene glycol } \\
\text { Dose: } 10 \mathrm{mg} / \mathrm{kg} \text { b.w }\end{array}$ & $\begin{array}{c}\text { Eliminated } \mathrm{CaOx} \text { deposition in kidney } \\
\text { Protected against deleterious effects (weight loss, impaired renal function, } \\
\text { and oxidative stress) } \\
\text { Elevated urine volume and } \mathrm{pH} \\
\text { Decreased } \mathrm{Ca}^{2+} \text { excretion }\end{array}$ & [56] \\
\hline $\begin{array}{l}\text { Hydroxyanthraquinones } \\
\text { (quinones) }\end{array}$ & $\begin{array}{l}\text { In vitro } \mathrm{CaOx} \text { crystallization assays using calcium chloride and } \\
\text { sodium oxalate }\end{array}$ & $\begin{array}{l}\text { Inhibited the formation of } \mathrm{CaOx} \\
\text { Increased the solubility of CaOx crystals and of real kidney stones }\end{array}$ & [43] \\
\hline $\begin{array}{l}\text { Oleanolic acid } \\
\text { (fatty acids) }\end{array}$ & $\begin{array}{l}\text { Zinc disc implantation }(20 \mathrm{mg}) \text { induced urolithiasis in albino } \\
\text { Wistar rats } \\
\text { Doses: } 60,80 \text {, and } 100 \mathrm{mg} / \mathrm{kg} / \text { day for } 7 \text { days }\end{array}$ & $\begin{array}{l}\text { Increased urine output } \\
\text { Reduced the calcium output } \\
\text { Reduced formation of depositions around the zinc disc } \\
\text { Reduced the formation of deposits around implanted disc }\end{array}$ & [58] \\
\hline $\begin{array}{l}\text { Four sulfated } \\
\text { polysaccharides: } \\
\text { (fucoglucoxyloglucuronan, } \\
\text { heterofucan, and } \\
\text { two glucans) }\end{array}$ & $\begin{array}{l}\text { CaOx crystallization assays } \\
\text { Sulfated polysaccharides }(0.25 \mathrm{mM})\end{array}$ & $\begin{array}{l}\text { Nucleation inhibition capacity varied between } 73.33 \% \text { and } 84.07 \% \\
\text { Aggregation inhibition varied between } 86 \% \text { and } 80 \% \\
\qquad \begin{aligned} \zeta=+2.0 \pm 0.45 \mathrm{mV} \text { for heterofucan } \\
\zeta=+4.5 \pm 1.77 \mathrm{mV} \text { for fucoglucoxyloglucuronan } \\
\zeta=+4.98 \pm 1.01 \mathrm{mV} \text { for glucans }(1) \\
\zeta=+4.19 \pm 0.9 \mathrm{mV} \text { for glucan }(2)\end{aligned}\end{array}$ & {$[44]$} \\
\hline
\end{tabular}


Table 4. Cont.

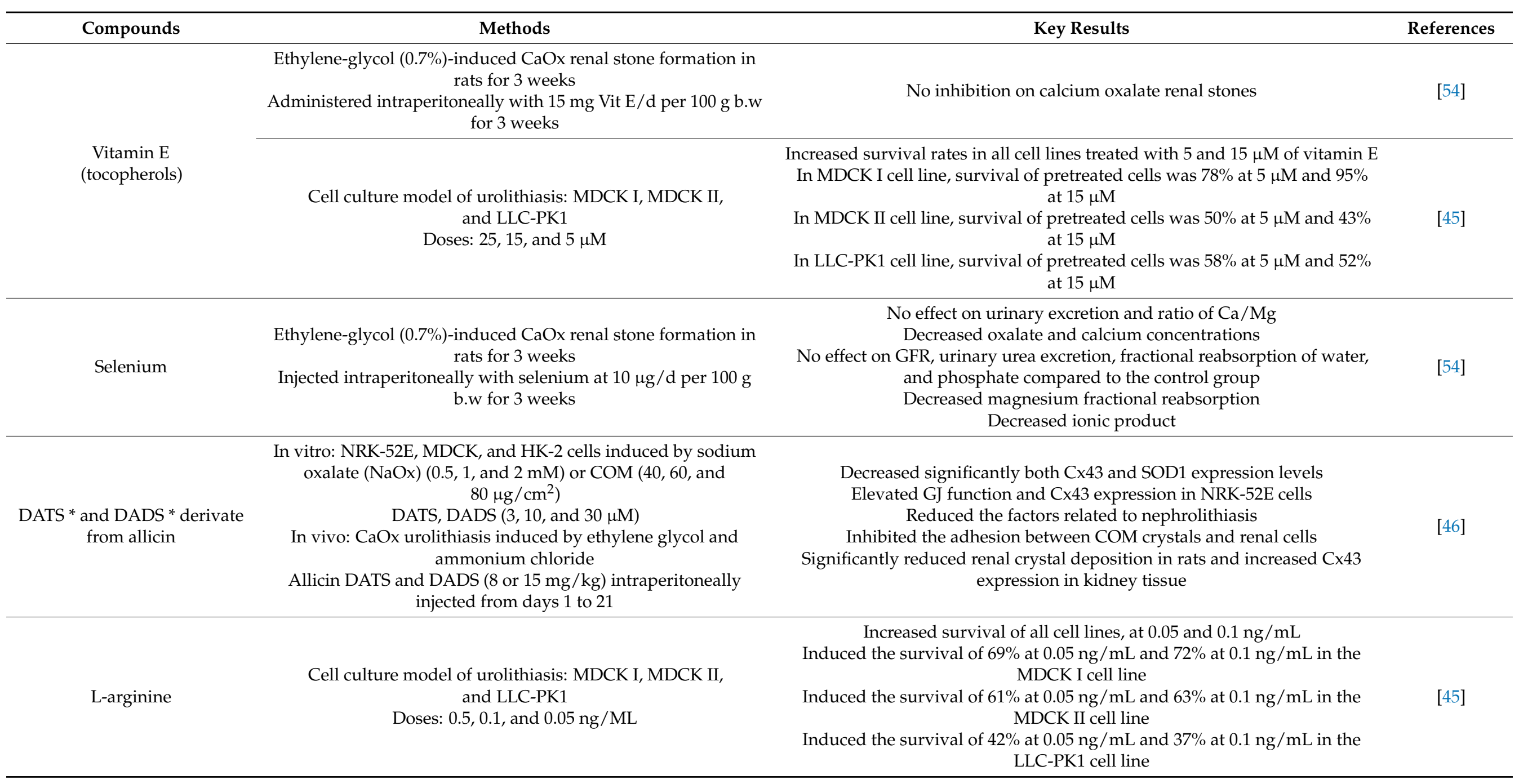


Table 4. Cont.

Compounds

Methods

Nephrolithiasis induced by ethylene glycol and ammonium chloride

Rottlerin

$$
1 \mathrm{mg} / \mathrm{kg} / \text { day }
$$

\section{Key Results}

References

Decreased LDH activity and inhibited lipid peroxidation

Enhanced the activities of antioxidant enzymes (CAT and SOD)

Refurbished MDA levels and redox ratio in hyperoxaluric rats

Ameliorated the renal cell injury

Ameliorated creatinine clearance and the levels of calcium and oxalate

in urine

* DATS diallyltrisulfide; DADS, diallyldisulfide. 


\subsection{In Vitro Investigations}

Several studies [43-48] have reported, in vitro, the effect of hydroxyanthraquinones, sulfated polysaccharides, L-arginine, vitamin E, DADS, DATS, betulin, and piperin on the prevention of nephrolithiasis formation using the crystallization process in human urine, titrimetric, conductometric titration, and crystal development in cell culture assays.

Frackowiak and colleagues investigated, in vitro, the anti-lithiasis effect of five hydroxyanthraquinones on $\mathrm{CaOx}$ crystal formation induced by sodium oxalate and calcium chloride using conductometric titration. 1,2,5,8-tetrahydroxy-9,10-anthraquinone and its glycosides inhibited the formation of $\mathrm{CaOx}$ more than other compounds $(\Delta \mathrm{EP}=180 \mu \mathrm{L}$, $\Delta \mathrm{EP}=170 \mu \mathrm{L}$, respectively) [43]. The author reported that the increase in the number of hydroxyl groups in the aglycone is the main factor responsible for good complexing properties.

The in vitro assay of four sulfated polysaccharides (fucoglucoxyloglucuronan, heterofucan, and two glucans from the brown seaweed Dictyopteris justii) on CaOx crystallization assays were carried out by Teodosio Melo et al. [44]. Heterofucan and glucan (1) inhibited the nucleation process with $73.33 \%$ and $84.07 \%$, respectively, while the inhibition of glucan (1) aggregation was greater than that of sodium citrate ( $86 \%$ vs. $84 \%)$. From this data, the authors suggested that glucans stabilize COD crystals and prevent them from turning into COM ones, which protects against urolithiasis. Furthermore, the zeta potential $(\zeta)$ of heterofucan was significantly reduced compared to the CaOx samples $(+2.00 \pm 0.45$ vs. $+8.39 \pm 1.79 \mathrm{mV}$, respectively) due to the greater negative charge compared to other sulfate polysaccharides [44].

In other work carried out by Kizivat et al. [45], L-arginine, at different concentrations $(0.5,0.1$, and $0.05 \mathrm{ng} / \mathrm{mL})$ was evaluated, in vitro, on renal cell lines from pigs and dogs (MDCK I, MDCK II, and LLC-PK1) induced by sodium oxalate in the concentration of $8 \mathrm{mM}$. Pretreatment with L-arginine significantly increased the survival of all cells in a dosedependent manner compared to oxalate-treated cells. At $0.05 \mathrm{ng} / \mathrm{mL}$, L-arginine showed a significant survival in MDCK I and MDCK II cell lines compared to oxalate treatment cells, but not for LLC-PK1 line ( $66 \%$ vs. $55 \%, 61 \%$ vs. $51 \%$, and $42 \%$ vs. $32 \%$, respectively). Vitamin E, at different concentrations $(25,15$, and $5 \mu \mathrm{M})$, has been investigated in vitro using the same experimental approach [45]. At 5 and $15 \mu \mathrm{M}$, vitamin E pretreatment significantly improved the survival of all cells compared to oxalate-alone-treated cells. L-arginine showed a significant survival in MDCK I and MDCK II cell lines, at $5 \mu \mathrm{M}$, compared to oxalate treatment cells, but not for the LLC-PK1 line ( $78 \%$ vs. $66 \%, 50 \%$ vs. $38 \%$, and $58 \%$ vs. $34 \%$, respectively). Kiziyat and colleagues indicated that vitamin E has the same effect on epithelial cell lines in different species, while L-arginine has different effects depending on the origin of the cell species [45]. Therefore, further investigations are necessary to determine the effect of these two compounds on human kidney epithelial cells and determine their mechanism of action.

The anti-crystallization activity of taraxasterol, at different concentrations $(2.5,5$, 7.5 , and $12.5 \mu \mathrm{g} / \mathrm{mL}$ ) on $\mathrm{CaOx}$ induced by sodium oxalate in synthetic urine, has been investigated by [49]. Taraxasterol inhibited the nucleation process in a dose-dependent manner (26-64\%). In addition, at $12.5 \mu \mathrm{g} / \mathrm{mL}$, this compound increased the number of COD crystals ( 52 vs. 25 for 10-15 $\mu \mathrm{m}$ size of COD crystals) and decreased COM crystals (125 vs. 195 for 10-15 $\mu \mathrm{m}$ size of COD crystals) compared to the control sample. Furthermore, taraxasterol decreased the size of COD crystals in a dose-dependent manner.

Lai et al. investigated, in vitro, the effect of DADS and DATS (derivative of allicin) at different concentrations ( 3,10 , and $30 \mu \mathrm{M}$ ) on cell lines (NRK-52E, MDCK, and HK-2 cells) induced by sodium oxalate $(\mathrm{NaOx})(0.5,1$, and $2 \mathrm{mM})$ or $\mathrm{COM}\left(40,60\right.$, and $\left.80 \mu \mathrm{g} / \mathrm{cm}^{2}\right)$. DATS inhibited the cytotoxicity of simvastatin on NRK-52E cells and increased Cx43 expression [46]. These authors reported that $C \times 43$ attenuated renal fibrosis by enhancing the activity of Nrf2/ARE pathways.

The effect of betulin (from Betula alba) at different concentrations $(5,10,20,40,80$, and $160 \mu \mathrm{g}$ ) on $\mathrm{CaOx}$ induced by sodium oxalate in urine samples [47]. The crystallization, 
nucleation, and aggregation phases are the three crystallization stages observed with betulin. At 5 and $160 \mu \mathrm{g}$, betulin has the same turbidity as cystone (positive control) $(0.150$ vs. 0.178 and 0.304 vs. 0.401 , respectively). Successively, using a microscope at the end of the experiment, an increase in the number of smaller-sized crystals at 80 and $160 \mu \mathrm{g}$ has been observed. The same observation has been observed for nucleation and aggregation assays. These authors suggested that betulin contains nucleation-preventing agents which inhibit the growth of $\mathrm{CaOx}$ crystals.

Recently, [48] evaluated, in vitro, the effect of piperine at different concentrations (10 and $20 \mathrm{mg} / \mathrm{kg}$ ) using the titrimetric method and aggregation assay. At $20 \mathrm{mg} / \mathrm{kg}$, piperine significantly inhibited the crystallization than piperine at $10 \mathrm{mg} / \mathrm{kg}$ compared to cystone (standard drug). However, the mechanism of action of piperine is still unknown.

\subsection{In Vivo Investigations}

The nephrolithiasis effect of the in vivo approach of taraxasterol, betulin, lupeol, khellin, visnagin, crocin, piperine, berberine, oleanolic acid, vitamin E, selenium, DADS, DATS, and rottlerin (Figure 5) was investigated by several researchers (Table 4) using several animal models, including oral administration of EG, EG with ammonium chloride, pyridoxine-deficient diet (PDD), or using the implantation of a foreign body (zing disc and glass bead) to mimic the etiology of urinary stone formation in humans [24,46,48-60].

Terpenoids, bioactive compounds widely distributed in nature, have specific and multiple molecular targets, such as the activation of NF- $\mathrm{B}$ transcription factors to inhibit the inflammatory signaling pathways [61], and the decrease in mitochondrial membrane potential $(\triangle \Psi \mathrm{m})$ in anticancer pathways [62]. Recently, thanks to new technologies and molecular biology, several researchers have reported, on the one hand, the nephrolithiasis efficacy of bioactive compounds and, on the other hand, the mechanistic pathways of these terpenoids. The authors of [50] have tested the effect of lupeol, a pentacyclic triterpene, for 16 weeks on urolithiasis induced by a glass bead (15-18 mg) implantation in rats. This study showed that lupeol $(10,25$, or $50 \mathrm{mg} / \mathrm{kg})$ significantly reduced, in a dosedependent manner, the weight of urolith formed in preventive treatment compared to curative treatment (20-95\% and 15.5-55\%, respectively, for the weight of urolith). In addition, at $50 \mathrm{mg} / \mathrm{kg}$, the urinary levels of calcium, inorganic phosphate, and oxalate (the major calculogenic substances) were very significantly reduced compared to lithiasis rats (7.44 vs. $11.68 \mathrm{mg} / \mathrm{dL}, 47.06$ vs. $59.8 \mathrm{mg} / \mathrm{dL}$, and 5.53 vs. $7.2 \mathrm{mg} / \mathrm{dL}$, respectively, in preventive treatment and 8.02 vs. $11.68 \mathrm{mg} / \mathrm{dL}, 49.74$ vs. $59.83 \mathrm{mg} / \mathrm{dL}$, and $7.21 \mathrm{vs}$. $8.89 \mathrm{mg} / \mathrm{dL}$, respectively, in curative treatment). The authors suggested that this reduction is mediated by dissolution or demineralization of the preformed mineral phase and also by the prevention of their deposition in the urinary bladder. After one year, another study was carried out by [51] on the use of lupeol against a hyperoxaluric Wistar strain induced by $2 \%$ ammonium oxalate. At $25 \mathrm{mg} / \mathrm{kg}$ for 15 days, the level of urinary oxalate was reduced compared to a lithogenic Wistar strain (8.15 vs. $13.63 \mathrm{mg} /$ day), while creatinine, citric acid, and glycosaminoglycans were normalized (10.36 vs. $13.20 \mathrm{mg} /$ day, 1.99 vs. $2.83 \mathrm{mg} /$ day, and 3.39 vs. $4.23 \mathrm{mg} /$ day, respectively). In addition, the major oxalate-synthesizing enzyme (LDH), the enzymes specific for the renal proximal tubules (ALP and gamma glutamyl transferase $(\gamma$-AGT) $)$, and the lysosomal marker enzymes ( $\beta$-glucuronidase and $\mathrm{N}$-acetyl $\beta$-D glucosaminidase (NAG)) were significantly reduced in urine compared to nephrolithiasis rats ( 0.39 vs. $0.73 \mu$ moles of pyruvate released/mg creatinine/day, 1.15 vs. $2.86 \mu$ moles of phenol released/mg creatinine/day, 5.07 vs. $8.33 \mu$ moles of p-nitroaniline released/mg creatinine/day, and 0.74 vs. $1.39 \mu$ moles of p-nitroaniline released/mg creatinine/day, respectively). In 2000, the same group [52] investigated, in vivo, the effect of lupeol isolated from the stem bark powder of Crataeva nurvala on urolithiasis induced by the insertion of a zinc piece in rats followed by $2 \%$ ammonium oxalate. From this experience, lupeol at $35 \mathrm{mg} / \mathrm{kg}$ restored non-enzymic antioxidant levels (GSH (4.56 vs. $4.68 \mu \mathrm{g} / \mathrm{mg}$ protein), TSH (11.02 vs. $12.25 \mu \mathrm{g} / \mathrm{mg}$ protein), NPSH (2.91 vs. $3.26 \mu \mathrm{g} / \mathrm{mg}$ protein), vitamin C (1.97 vs. $2.13 \mu \mathrm{g} / \mathrm{mg}$ protein), and vitamin E (0.45 vs. $0.48 \mu \mathrm{g} / \mathrm{mg}$ 
protein)) and antioxidant enzymes (SOD (6.34 vs. 6.54 units/min/mg protein), GPx (9.57 vs. 10.30 units $/ \mathrm{min} / \mathrm{mg}$ protein), and CAT (151.13 vs. 170.11 units/min/mg protein)) in the kidneys compared to normal rats. At the same time, lupeol improved glutathione-related enzymes (glutathione-S-transferase (GST), glutathione reductase (GR), and glucose-6phosphate dehydrogenase (G6PD)) in the kidneys compared to lithiasis rats. The same restorative effect was observed in the bladder. Additionally, lupeol reduced the level of oxalate supersaturation in tissues. The authors reported that the anti-lithiasis effect of lupeol was involved in different mechanisms, including cytoprotective activity, inhibition of oxalate-induced toxic manifestations, and reduction of free radical production. More interesting, the anti-nephrolithiasis effect of lupeol was evaluated in a rat lithiasis model giving a PDD containing 3\% glycolic acid. The oral administration of lupeol (extracted from Crataeva nurvala) at $35 \mathrm{mg} / \mathrm{Kg}$ by [53] showed a significant reduction in oxalate and calcium to normal values ( 2.74 vs. $2.83 \mathrm{mg} /$ day and 0.30 vs. $0.31 \mathrm{mg} /$ day, respectively) while no significant reduction was observed for uric acid. Simultaneously, lupeol restored the excretion of magnesium and glycosaminoglycans (GAG) to normal (1.05 vs. $1.26 \mathrm{mg} /$ day and 0.56 vs. $0.58 \mathrm{mg}$ /day, respectively) and significantly reduced the excretion of GGT and the lysosomal marker enzymes of the kidneys (Glu and $\mathrm{NaG}$ ) to normal compared to lithiasis rats $(2.40 \mathrm{vs} .3 .73$ units $/ \mathrm{mg}$ creatinine/h, 0.28 vs. 0.72 units $/ \mathrm{mg}$ creatinine $/ \mathrm{h}$, and 0.29 vs. 0.76 units /mg creatinine/h, respectively). Furthermore, LDH excretion was significantly reduced compared to lithiasis rats ( 0.40 vs. 0.51 units $/ \mathrm{mg}$ creatinine $/ \mathrm{h})$. In 2008, lupeol at $50 \mathrm{mg} / \mathrm{Kg} /$ day for 28 days enhanced the activities of both renal marker enzymes (ALP and $\gamma-\mathrm{GT}$ ) and antioxidant enzymes (SOD, CAT, and GPx), reduced the activity of glycolic acid oxidase (GAO), and restricted the oxalate-induced peroxidase changes in kidney tissue [55]. The authors suggested that this effect was achieved by the transmembrane stabilizing effects, due to the increase in the surface area/volume of the cells, and by the antioxidant activity, due to the $\mathrm{CH} 3$ group present in the $\mathrm{C}-17$ position of the lupeol structure.

Further, few authors evaluated, in vivo, the effect of other terpenoids on urolithiasis rats [24,52]. The nephrolithiasis effect of betulin at $35 \mathrm{mg} / \mathrm{Kg} /$ day for 15 days was evaluated in urolithiasis induced by the insertion of a piece of zinc (10-12 mg) followed by $2 \%$ of ammonium oxalate [52]. In this study, betulin restored the levels of non-enzymic antioxidants (GSH, NPSH, vitamin C, and vitamin E) and antioxidant enzymes (SOD, GPx, and CAT), and glutathione-related enzymes (GST, GR, and G6PD) in the kidneys and bladder. In parallel, the level of oxalate supersaturation in the tissues was reduced. Recently, [24] evaluated the effect of the same compound (isolated from Aerva lanata) on nephrolithiasis rats induced by EG $0.75 \%$. At $2 \mathrm{mg} / \mathrm{kg} /$ day for 28 days, betulin significantly increased urine volume $(21.50 \mathrm{~mL})$, excretion of calcium, oxalate, phosphate, and magnesium levels. At the same time, betulin significantly reduced the level of BUN, creatinine, and the size of calculi. The authors suggested that betulin acts through different mechanisms, including the diuretic effect, inhibition of the oxalate oxidase enzyme responsible for stone formation, and reducing the risk of obstructed urine flow.

Only one piece of research elaborated by Vanachayangkul et al. [57] reported the effect of two furanochromes (khellin and visnagin) on EG-induced hyperoxaluria in rats. In this study, khellin and visnagin at 5 and $10 \mathrm{mg} / \mathrm{kg} /$ day significantly decreased the incidence of $\mathrm{CaOx}$ crystal deposition in animals in the nephrolithiasisc group. Whereas these two compounds did not affect urinary parameters ( $\mathrm{pH}$, citrate, calcium, and oxalate), from this study, the authors suggested that khellin and visnagin interfere with calcium blocking activity and not with citrate reabsorption [57].

Carotenoids are proven to play an important role in nutrition and health [63]. However, the effect of carotenoids on kidney stone formation is lacking. One compound, crocin, has been investigated for its nephrolithiasis activity. The prophylactic and curative effect of crocin, the main water-soluble carotenoid of Crocus sativus, was evaluated by [59] at different concentrations $(10,20$, and $40 \mathrm{mg} / \mathrm{kg} /$ day) in urolithiasis rats. In the prophylactic effect, at $20 \mathrm{mg} / \mathrm{kg} /$ day, crocin significantly reduced the level of urinary oxalate (2.05 
vs. $5.2 \mathrm{mg}$ /day, respectively), urinary protein ( 0.98 vs. $2.35 \mathrm{mg} /$ day, respectively), $\mathrm{CaOx}$ crystal deposition number (306 vs. 727), and MDA (33 vs. $62 \mathrm{nmol} / \mathrm{g}$ tissue) compared to lithiasis rats. At the same time, crocin significantly enhanced the level of urinary citrate and magnesium in urolithiasis rats treated at $20 \mathrm{mg} / \mathrm{kg} /$ day compared to lithiasis rats (3.61 vs. $2.7 \mathrm{mg} /$ day and 2.11 vs. $0.42 \mathrm{mg} /$ day, respectively), while neither the urinary ionic parameters nor the number of crystals were significantly altered in the curative treatment.

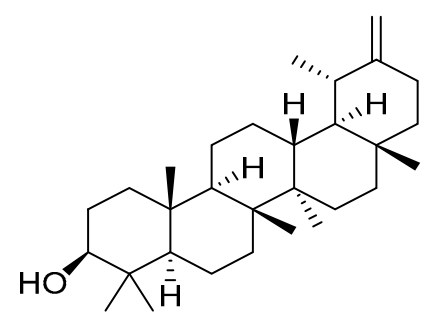

1: Taraxasterol<smiles>COc1c2occc2c(OC)c2c(=O)cc(C)oc12</smiles>

4: Khellin

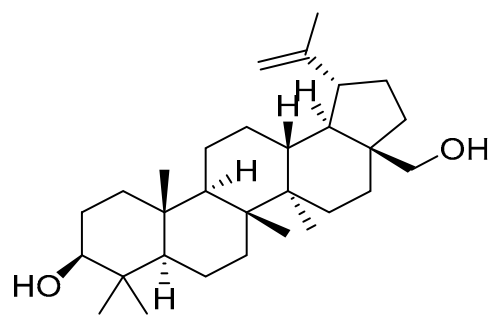

2: Betulin

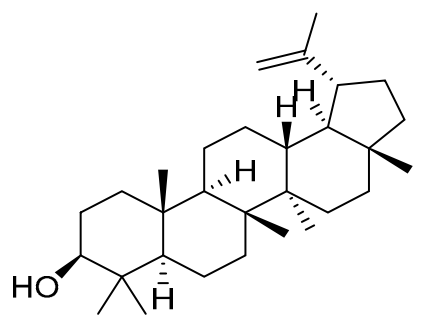

3: Lupeol<smiles>COc1c2ccoc2cc2oc(C)cc(=O)c12</smiles>

5: Visnagin<smiles>O=C(/C=C/C=C/c1ccc2c(c1)OCO2)N1CCCCC1</smiles>

6: Piperine

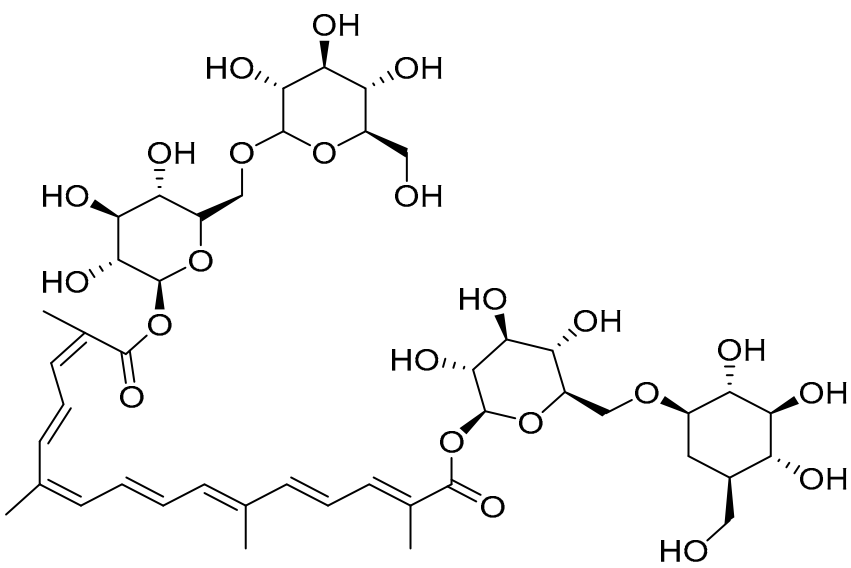<smiles></smiles>

8: Berberine<smiles>Cc1c(C)c2c(c(C)c1O)CC[C@@](C)(CCC[C@H](C)CCC[C@H](C)CCCC(C)C)O2</smiles>

9:Vitamin $\mathrm{E}$

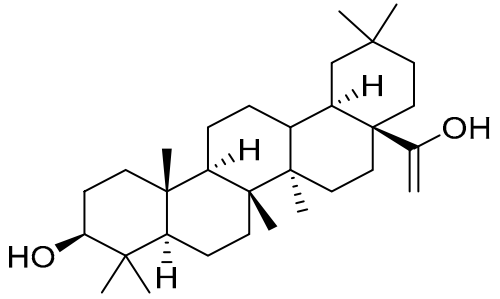

10: Oleanolic acid

Figure 5. Chemical structures of other compounds with in vivo litholytic effects. 
Furthermore, two authors evaluated, in vivo, the effect of two alkaloids (berberine and piperine) on $\mathrm{CaOx}$ urolithiasis in rats [48,56]. Bashir et al. [56] evaluated the preventive and curative effects of berberine. At $10 \mathrm{mg} / \mathrm{kg}$, this isoquinoline alkaloid significantly reduced crystal count and water intake compared to EG-induced nephrolithiasis in rats (6.17 vs. 53.6 crystal count/field and 12.3 vs. $21.5 \mathrm{~mL}$, respectively). In parallel, berberine significantly increased the levels of urinary $\mathrm{pH}$ and urinary volume (6.59 vs. 5.35 and 13.7 vs. $6.67 \mathrm{~mL}$, respectively), and decreased $\mathrm{Ca}^{2+}$ excretion compared to normal rats (2.05 vs. $3.33 \mathrm{mg}$ ) [56]. The markers of glomerular and tubular damages (BUN, serum creatinine, and creatinine clearance) were significantly reduced ( 24.8 vs. 63.7, 0.95 vs. $1.43 \mathrm{mg} / \mathrm{dL}$, and 0.81 vs. $0.53 \mathrm{~mL} / \mathrm{min}$, respectively). At the same concentration, this compound protects significantly against changes associated with oxidative stress. The contents of MDA and carbonyl protein were reduced very significantly while GSH was enhanced significantly compared to lithiasis rats (1.63 vs. $13.3 \mathrm{nmol} / \mathrm{mg}$ protein, 6.39 vs. $11.20 \mathrm{nmol} / \mathrm{mg}$ protein, and $17.2 \mathrm{vs.} 11.6 \mathrm{nmol} / \mathrm{mg}$ protein, respectively) [56]. In curative treatment, a non-significant decrease in urine volume and water intake, as well as an increase in urine $\mathrm{pH}$, were recorded. Whereas the crystal counts, urinary oxalate, and BUN have been significantly reduced (14.5 vs. 32 crystal count/field, 0.43 vs. $0.69 \mathrm{mg}$, and 23.01 vs. 39.13, respectively). These findings suggest that khellin nephrolithiasis activity is mediated by a combination of antioxidant, diuretic, hypocalciuric, and urinealkalinizing activities. Recently, Suvarna et al. [48] have evaluated, in vivo, the urolithiasis effect of piperine against hyperoxaluria induced in Wistar rats. The results showed that this alkaloid ameliorated the serum parameters (calcium, urea, uric acid, and creatinine) and urine parameters (calcium and oxalate) [48].

The anti-urolithiatic activity of fatty acid was reported by Vyas et al. [58]. Wistar male rats treated orally with oleanolic acid, from roots of Lantana camara, at different concentrations $(60,80$, and $100 \mathrm{mg} / \mathrm{kg}$ /day) demonstrated an increase in urinary volume and a significant reduction in calcium urinary excretion compared to zinc disc implantation (1.9 vs. $1.6 \mathrm{~mL}$, and 12 vs. $23 \mathrm{mg} / \mathrm{dL}$, respectively at $60 \mathrm{mg} / \mathrm{kg} /$ day). In addition, oleanolic acid significantly reduced the weight of zinc discs as well as the deposited crystals (11 vs. $111 \mathrm{mg}$ ). From this research, the authors suggested that the increased urine output is mediated by activation of the muscarinic receptor in the bladder muscles.

Tocopherol, a fat-soluble nutrient, exhibited several pharmacological effects, including antiproliferative, antioxidant, and neuroprotective activities [64,65]. The anti-lithiasis activity of tocopherols (vitamin E) was tested in vivo on EG-induced kidney stones in a rat model by intraperitoneal administration with $15 \mathrm{mg} / 100 \mathrm{~g} \mathrm{b.w} \mathrm{[54].} \mathrm{This} \mathrm{dose} \mathrm{did} \mathrm{not}$ inhibit $\mathrm{CaOx}$ stone formation in rats.

In animals treated with EG (hyperoxaluric rats), selenium at $10 \mu \mathrm{g} / 100 \mathrm{~g}$ decreased the reabsorption of the magnesium fraction, the ionic product $(4.03 \mathrm{vs} .6 .72 \mathrm{mg} / \mathrm{g}$ ), and the oxalate and calcium concentrations ( 0.81 vs. $1 \mathrm{mg} / \mathrm{g}$ and $4.98 \mathrm{vs} .6 .11$, respectively) [54]. In contrast, no effect on urinary excretion, urinary urea excretion, $\mathrm{Ca} / \mathrm{Mg}$ ratio, GFR, and fractional reabsorption of water and phosphate compared to the control group was reported.

Chhiber et al. [60] investigated, in vivo, the antilithiasic effect of rottlerin (from the fruits of Mallotus phillipensis (Lam.)) at $1 \mathrm{mg} / \mathrm{kg} /$ day on CaOx induced by the administration of $0.4 \%$ EG and $1 \%$ ammonium chloride. At $1 \mathrm{mg} / \mathrm{kg} / \mathrm{day}$, rottlerin enhanced the activities of antioxidant enzymes (CAT and SOD) and refurbished MDA levels and the redox ratio in hyperoxaluric rats. Additionally, rottlerin maintained creatinine clearance (2.43 vs. $2.84 \mathrm{~mL} / \mathrm{min}$ ) and urinary excretion of calcium and oxalate (3.35 vs. $2.88 \mathrm{mg} / \mathrm{dL}$ and 1.13 vs. $0.92 \mathrm{mg} /$ day, respectively) compared to normal rats [60], whereas no significant change in the level of alkaline phosphatase in the serum has been reported. Furthermore, rottlerin significantly decreased the activity of LDH and lipid peroxidation in nephrolithiasis rats (41.28 vs. $49.74 \mathrm{IU} / \mathrm{L}$ and 5 vs. $10 \mathrm{nmol}$ of MDA formed/mg protein, respectively). The authors confirmed that rottlerin decreased the translocation of protein kinase $\mathrm{C} \delta$ (PKC $\delta$ ) from the cytoplasmic fraction to the membrane and the mitochondrial fraction, suggesting an inhibition of PKC $\delta$ activity as well as a reduction in NADPH oxidase activ- 
ity [60]. These findings suggest further studies to determine the mechanisms by which these compounds exactly act. Moreover, clinical investigations of these compounds were also suggested in many different studies.

The antiurolithiatis effect of taraxasterol at different concentrations $(2,4$, and $8 \mathrm{mg} / \mathrm{kg})$ on EG-induced urolithiasis rats was evaluated by Yousefi Ghale-Salimi et al. [49]. At $2 \mathrm{mg} / \mathrm{kg}$, taraxasterol exhibited a potent and very significant decrease in hepatic and renal coefficients in vivo ( 0.029 vs. 0.042 and 0.004 vs. 0.008 , respectively). Serum analysis revealed a significant decrease in calcium, ALT, AST, and LDH levels compared to lithiasis rats (12.5 vs. $13.5 \mathrm{mg} / \mathrm{dL}, 43.9$ vs. $52.2 \mathrm{UI} / \mathrm{L}, 44.8$ vs. $49.5 \mathrm{UI} / \mathrm{L}$, and 1105 vs. $1318 \mathrm{UI} / \mathrm{L}$, respectively), while serum albumin, magnesium, SOD, and GPx levels increased (3.6 vs. $3 \mathrm{mg} / \mathrm{dL}, 0.86$ vs. $0.78 \mathrm{mg} / \mathrm{dL}, 90 \mathrm{vs} .81 \mathrm{UI} / \mathrm{L}$, and 226 vs. $210 \mathrm{UI} / \mathrm{L}$, respectively) [49]. In parallel, taraxasterol significantly reduced the score of crystal deposits, pathological damage, and inflammation compared to lithiasis rats ( 3.5 vs. $5.5,2$ vs. 5.3 , and 0 vs. 2.5 , respectively). These authors suggest that taraxasterol interacts with CaOx crystals, promotes oxidative enzymes (SOD and GPx), and reduces inflammatory cytokines such as TNF- $\alpha$, IL-6, and IL-1 $\beta$, which reduce the production of ROS.

Recently, Lai et al. [46] evaluated in vivo the effect of DADS and DATS at different concentrations ( 8 and $15 \mathrm{mg} / \mathrm{kg}$ ) on urolithiasis induced by EG and ammonium chloride in rats. DADS and DATS significantly increased Cx43 and SOD1 expression levels in the model group compared to expression levels in the control group. Furthermore, allicin significantly decreased renal crystal deposition in rats and increased Cx43 expression in kidney. From this research, the authors suggested that DADS and DATS modulate GJs, Cxs, inflammation, and oxidative stress, which prevent nephrolithiasis [46].

\section{Conclusions and Perspectives}

The bioactive molecules isolated and identified from medicinal plants exhibit remarkable anti-litholitic effects. These effects are mediated by a wide variety of molecular mechanisms, including the prevention of ROS formation and the inhibition of crystallization processes. However, the experimental approaches that have been carried out with these natural substances remain preclinical results. In addition, the clinical studies investigated the effects of these natural drugs on human have not been explored. Therefore, future studies regarding clinical applications could be a promising strategy to validate the clinical applications of these drugs. Indeed, clinical investigations were the major limitation in our review, because our research did not reveal studies that evaluated the urolithiasis effects of these natural compounds on humans. Furthermore, further clinical investigations of these compounds need their safety validated. In this way, it will also be essential to determine the toxicity of these natural substances in order to be able to apply them in clinical terms.

Author Contributions: Conceptualization: N.E.M., A.K. and N.E.O.; Methodology: N.E.M., A.K., N.E.O. and A.B.; Formal Analysis and Investigation: A.B. and G.Z.; Writing-Original Draft Preparation: N.E.M., A.K., N.E.O. and A.B.; Writing-Review and Editing: N.E.M., A.K., N.E.O., A.B. and G.Z.; Funding Acquisition: A.B. and M.G.; Resources: A.B.; Revising and Visualization: G.Z., M.G. and D.M.; Supervision: G.Z., M.G. and D.M. All authors have read and agreed to the published version of the manuscript.

Funding: This research received no external funding.

Institutional Review Board Statement: Not applicable.

Informed Consent Statement: Not applicable.

Data Availability Statement: All data presented herein are available in the published literature.

Conflicts of Interest: The authors declare no conflict of interest. 


\section{References}

1. Ziemba, J.B.; Matlaga, B.R. Epidemiology and Economics of Nephrolithiasis. Investig. Clin. Urol. 2017, 58, 299-306. [CrossRef]

2. Khan, S.R.; Pearle, M.S.; Robertson, W.G.; Gambaro, G.; Canales, B.K.; Doizi, S.; Tiselius, H.G. Kidney stones. Nat. Rev. Dis. Primers 2016, 2, 16008. [CrossRef]

3. Ghelani, H.; Chapala, M.; Jadav, P. Diuretic and Antiurolithiatic Activities of an Ethanolic Extract of Acorus calamus L. Rhizome in Experimental Animal Models. J. Tradit. Complement. Med. 2016, 6, 431-436. [CrossRef]

4. Romero, V.; Akpinar, H.; Assimos, D.G. Kidney Stones: A Global Picture of Prevalence, Incidence, and Associated Risk Factors. Rev. Urol. 2010, 12, 86-96.

5. Aggarwal, A.; Singla, S.K.; Tandon, C. Urolithiasis: Phytotherapy as an Adjunct Therapy. IJEB 2014, 52, $103-111$.

6. Atmani, F.; Slimani, Y.; Mimouni, M.; Aziz, M.; Hacht, B.; Ziyyat, A. Effect of Aqueous Extract from Herniaria hirsuta L. on Experimentally Nephrolithiasic Rats. J. Ethnopharmacol. 2004, 95, 87-93. [CrossRef]

7. Amengual-Cladera, E.; Nadal-Casellas, A.; Gómez-Pérez, Y.; Gomila, I.; Prieto, R.M.; Proenza, A.M.; Lladó, I. Phytotherapy in a Rat Model of Hyperoxaluria: The Antioxidant Effects of Quercetin Involve Serum Paraoxonase 1 Activation. Exp. Biol. Med. 2011, 236, 1133-1138. [CrossRef] [PubMed]

8. Bensatal, A.; Rahmoun, D.; Ardja, S.A.; Cheikh, M.; Kahouadji, A.; Bekhit, M. In Vitro Antilithiasic Activity of Saponins Rich Fraction from the Leaves of Zizyphus Lotus. Int. J. Green Pharm. 2020, 14, 280. [CrossRef]

9. Stiani, S.N.; Syahidah, F.M.; Fikriani, H.; Subarnas, A.; Rusdiana, T. Anticalculi Activity of Apigenin and Celery (Apium Graveolens L.) Extract in Rats Induced by Ethylene Glycol-Ammonium Chloride. J. Pharm. Bioallied. Sci. 2019, 11, S556-S561. [CrossRef] [PubMed]

10. Li, X.; Wu, G.; Shang, P.; Bao, J.; Lu, J.; Yue, Z. Anti-Nephrolithic Potential of Catechin in Melamine-Related Urolithiasis via the Inhibition of ROS, Apoptosis, Phospho-P38, and Osteopontin in Male Sprague-Dawley Rats. Free Radic. Res. 2015, 49, 1249-1258. [CrossRef] [PubMed]

11. Zhai, W.; Zheng, J.; Yao, X.; Peng, B.; Liu, M.; Huang, J.; Wang, G.; Xu, Y. Catechin Prevents the Calcium Oxalate Monohydrate Induced Renal Calcium Crystallization in NRK-52E Cells and the Ethylene Glycol Induced Renal Stone Formation in Rat. BMC Complement. Altern. Med. 2013, 13, 228. [CrossRef]

12. Prywer, J.; Olszynski, M.; Mielniczek Brzóska, E. Green Tea and Struvite Crystals in Relation to Infectious Urinary Stones: The Role of (-)-Epicatechin. Cryst. Growth Des. 2017, 17, 5953-5964. [CrossRef]

13. Gandhi, C.N.; Balaraman, R. Effect of Curcumin in the Prevention of Experimentally Induced Nephrolithiasis in Rats by Ethylene Glycol and Vitamin D3. Orient. Pharm. Exp. Med. 2009, 9, 259-267. [CrossRef]

14. Rahman, M.U.; Khan, J.; Jeyabalan, G.; Parveen, G. Antiurolithiatic Activity of Curcumin against Ethylene Glycol-Induced Urolithiasis in Male Wistar Rats. Int. J. Adv. Pharm. Med. Bioallied Sci. 2018, 6, 104-110.

15. Ghodasara, J.; Pawar, A.; Deshmukh, C.; Kuchekar, B. Inhibitory Effect of Rutin and Curcumin on Experimentally-Induced Calcium Oxalate Urolithiasis in Rats. Pharmacogn. Res. 2010, 2, 388. [CrossRef]

16. Sekkoum, K.; Belboukhari, N.; Cheriti, A.; Lahmer, N.; Naas, A. In Vitro Effect of Hesperidin \& Hesperitin on Calcium Oxalate Crystallization: The Chiral Impact. PhytoChem BioSub J. 2014, 8, 51-58. [CrossRef]

17. Oksay, T.; Yunusoğlu, S.; Calapoğlu, M.; Aydın Candan, İ.; Onaran, İ.; Ergün, O.; Özorak, A. Protective Impact of Resveratrol in Experimental Rat Model of Hyperoxaluria. Int. Urol. Nephrol. 2017, 49, 769-775. [CrossRef] [PubMed]

18. Hyuk Hong, S.; Lee, H.-J.; Jung Sohn, E.; Ko, H.-S.; Sang Shim, B.; Seok Ahn, K.; Kim, S.-H. Anti-Nephrolithic Potential of Resveratrol via Inhibition of ROS, MCP-1, Hyaluronan and Osteopontin in Vitro and in Vivo. Pharmacol. Rep. 2013, 65, 970-979. [CrossRef]

19. Zhu, W.; Xu, Y.; Feng, Y.; Peng, B.; Che, J.; Liu, M.; Zheng, J. Prophylactic Effects of Quercetin and Hyperoside in a Calcium Oxalate Stone Forming Rat Model. Urolithiasis 2014, 42, 519-526. [CrossRef] [PubMed]

20. Park, H.K.; Jeong, B.C.; Sung, M.-K.; Park, M.-Y.; Choi, E.Y.; Kim, B.S.; Kim, H.H.; Kim, J.I. Reduction of Oxidative Stress in Cultured Renal Tubular Cells and Preventive Effects on Renal Stone Formation by the Bioflavonoid Quercetin. J. Urol. 2008, 179, 1620-1626. [CrossRef] [PubMed]

21. Rashed, T.; Menon, M.; Thamilselvan, S. Molecular Mechanism of Oxalate-Induced Free Radical Production and Glutathione Redox Imbalance in Renal Epithelial Cells: Effect of Antioxidants. Am. J. Nephrol. 2004, 24, 557-568. [CrossRef]

22. Ding, T.; Zhao, T.; Li, Y.; Liu, Z.; Ding, J.; Ji, B.; Guo, Z. Vitexin exerts protective effects against calcium oxalate crystal-induced kidney pyroptosis in vivo and in vitro. Phytomedicine 2021, 86, 153562. [CrossRef]

23. Gomathi, S.; Sasikumar, P.; Anbazhagan, K.; Neha, S.A.; Sasikumar, S.; Selvi, M.S.; Selvam, G.S. Oral Administration of Indigenous Oxalate Degrading Lactic Acid Bacteria and Quercetin Prevents Calcium Oxalate Stone Formation in Rats Fed with Oxalate Rich Diet. J. Funct. Foods 2015, 17, 43-54. [CrossRef]

24. Dinnimath, B.M.; Jalalpure, S.S.; Patil, U.K. Antiurolithiatic Activity of Natural Constituents Isolated from Aerva Lanata. J. Ayurveda Integr. Med. 2017, 8, 226-232. [CrossRef] [PubMed]

25. Li, Y.; Zhang, J.; Liu, H.; Yuan, J.; Yin, Y.; Wang, T.; Cheng, B.; Sun, S.; Guo, Z. Curcumin Ameliorates Glyoxylate-Induced Calcium Oxalate Deposition and Renal Injuries in Mice. Phytomedicine 2019, 61, 152861. [CrossRef] [PubMed]

26. Gao, B.; Yasui, T.; Itoh, Y.; Li, Z.; Okada, A.; Tozawa, K.; Hayashi, Y.; Kohri, K. Association of Osteopontin Gene Haplotypes with Nephrolithiasis. Kidney Int. 2007, 72, 592-598. [CrossRef] [PubMed] 
27. Icer, M.A.; Gezmen-Karadag, M. The Multiple Functions and Mechanisms of Osteopontin. Clin. Biochem. $2018,59,17-24$. [CrossRef]

28. Hashemzaei, M.; Far, A.D.; Yari, A.; Heravi, R.E.; Tabrizian, K.; Taghdisi, S.M.; Sadegh, S.E.; Tsarouhas, K.; Kouretas, D.; Tzanakakis, G.; et al. Anticancer and Apoptosis-Inducing Effects of Quercetin in Vitro and in Vivo. Oncol. Rep. 2017, 38, 819-828. [CrossRef]

29. Li, Y.; Yao, J.; Han, C.; Yang, J.; Chaudhry, M.T.; Wang, S.; Liu, H.; Yin, Y. Quercetin, Inflammation and Immunity. Nutrients 2016, 8, 167. [CrossRef]

30. Rauf, A.; Imran, M.; Khan, I.A.; Ur-Rehman, M.-; Gilani, S.A.; Mehmood, Z.; Mubarak, M.S. Anticancer Potential of Quercetin: A Comprehensive Review. Phytother. Res. 2018, 32, 2109-2130. [CrossRef]

31. Heleno, S.A.; Martins, A.; Queiroz, M.J.R.P.; Ferreira, I.C.F.R. Bioactivity of Phenolic Acids: Metabolites versus Parent Compounds: A Review. Food Chem. 2015, 173, 501-513. [CrossRef]

32. Huang, Y.; Huang, R.; Zheng, X. Effect of Rosmarinic Acid on Renal Calcium Oxalate Stone Formation in Rats. Chin. J. Hosp. Pharm. 2011.

33. Yasir, F.; Wahab, A.-T.; Choudhary, M.I. Protective Effect of Dietary Polyphenol Caffeic Acid on Ethylene Glycol-Induced Kidney Stones in Rats. Urolithiasis 2018, 46, 157-166. [CrossRef]

34. Zhao, B.; Su, B.; Zhang, H.; Liu, W.; Du, Q.; Li, Y. Antiurolithiatic Effect of Ferulic Acid on Ethylene Glycolinduced Renal Calculus in Experimental Rats. Trop. J. Pharm. Res. 2019, 18, 109. [CrossRef]

35. Queiroz, M.F.; Melo, K.R.T.; Sabry, D.A.; Sassaki, G.L.; Rocha, H.A.O.; Costa, L.S. Gallic Acid-Chitosan Conjugate Inhibits the Formation of Calcium Oxalate Crystals. Molecules 2019, 24, 2074. [CrossRef] [PubMed]

36. Moser, J.C.; Cechinel-Zanchett, C.C.; Mariano, L.N.B.; Boeing, T.; da Silva, L.M.; de Souza, P. Diuretic, Natriuretic and Ca2+Sparing Effects Induced by Rosmarinic and Caffeic Acids in Rats. Rev. Bras. Farmacogn. 2020. [CrossRef]

37. Hayes, M. Chitin, Chitosan and their Derivatives from Marine Rest Raw Materials: Potential Food and Pharmaceutical Applications. In Marine Bioactive Compounds: Sources, Characterization and Applications; Hayes, M., Ed.; Springer: Boston, MA, USA, 2012; pp. 115-128; ISBN 978-1-4614-1247-2.

38. Hussain, Z.; Thu, H.E.; Shuid, A.N.; Katas, H.; Hussain, F. Recent Advances in Polymer-Based Wound Dressings for the Treatment of Diabetic Foot Ulcer: An Overview of State-of-the-Art. Curr. Drug. Targets 2018, 19, 527-550. [CrossRef]

39. Wieckiewicz, M.; Boening, K.W.; Grychowska, N.; Paradowska-Stolarz, A. Clinical Application of Chitosan in Dental Specialities. Mini Rev. Med. Chem. 2017, 17, 401-409. [CrossRef] [PubMed]

40. Wada, M.; Nishimura, Y.; Watanabe, Y.; Takita, T.; Innami, S. Accelerating Effect of Chitosan Intake on Urinary Calcium Excretion by Rats. Biosci. Biotechnol. Biochem. 1997, 61, 1206-1208. [CrossRef] [PubMed]

41. Espíndola, K.M.M.; Ferreira, R.G.; Narvaez, L.E.M.; Silva Rosario, A.C.R.; da Silva, A.H.M.; Silva, A.G.B.; Vieira, A.P.O.; Monteiro, M.C. Chemical and Pharmacological Aspects of Caffeic Acid and Its Activity in Hepatocarcinoma. Front. Oncol. $2019,9,541$. [CrossRef]

42. Umekawa, T.; Iguchi, M.; Kurita, T. The Effect of Osteopontin Immobilized Collagen Granules in the Seed Crystal Method. Urol. Res. 2001, 29, 282-286. [CrossRef]

43. Frąckowiak, A.; Skibiński, P.; Gaweł, W.; Zaczyńska, E.; Czarny, A.; Gancarz, R. Synthesis of Glycoside Derivatives of Hydroxyanthraquinone with Ability to Dissolve and Inhibit Formation of Crystals of Calcium Oxalate. Potential Compounds in Kidney Stone Therapy. Eur. J. Med. Chem. 2010, 45, 1001-1007. [CrossRef]

44. Teodosio Melo, K.; Gomes Camara, R.; Queiroz, M.; Jacome Vidal, A.; Machado Lima, C.; Melo-Silveira, R.; Almeida-Lima, J.; Oliveira Rocha, H. Evaluation of Sulfated Polysaccharides from the Brown Seaweed Dictyopteris Justii as Antioxidant Agents and as Inhibitors of the Formation of Calcium Oxalate Crystals. Molecules 2013, 18, 14543-14563. [CrossRef] [PubMed]

45. Kizivat, T.; Smolić, M.; Marić, I.; Tolušić Levak, M.; Smolić, R.; Bilić Čurčić, I.; Kuna, L.; Mihaljević, I.; Včev, A.; Tucak-Zorić, S. Antioxidant Pre-Treatment Reduces the Toxic Effects of Oxalate on Renal Epithelial Cells in a Cell Culture Model of Urolithiasis. IJERPH 2017, 14, 109. [CrossRef] [PubMed]

46. Lai, Y.; Liang, X.; Zhong, F.; Wu, W.; Zeng, T.; Huang, J.; Duan, X.; Li, S.; Zeng, G.; Wu, W. Allicin Attenuates Calcium Oxalate Crystal Deposition in the Rat Kidney by Regulating Gap Junction Function. J. Cell Physiol. 2019, 234, 9640-9651. [CrossRef]

47. Nirala, R.K.; Dutta, P.; Malik, M.Z.; Dwivedi, L.; Shrivastav, T.G.; Thakur, S.C. In Vitro and In Silico Evaluation of Betulin on Calcium Oxalate Crystal Formation. J. Am. Coll. Nutr. 2019, 38, 586-596. [CrossRef]

48. Suvarna, Y.; Rahaman, S.K.A. In Vitro-In Vivo Evaluation of Antiurolithiatic Activity of Piperine from Piper Nigrum. Res. J. Pharm. Technol. 2020, 13, 63-68. [CrossRef]

49. Yousefi Ghale-Salimi, M.; Eidi, M.; Ghaemi, N.; Khavari-Nejad, R.A. Antiurolithiatic Effect of the Taraxasterol on Ethylene Glycol Induced Kidney Calculi in Male Rats. Urolithiasis 2018, 46, 419-428. [CrossRef]

50. Anand, R.; Patnaik, G.K.; Kulshreshtha, D.K.; Dhawan, B.N. Antiurolithiatic Activity of Lupeol, the Active Constituent Isolated from Crateva Nurvala. Phytother. Res. 1994, 8, 417-421. [CrossRef]

51. Malini, M.M.; Baskar, R.; Varalakshmi, P. Effect of Lupeol, a Pentacyclic Triterpene, on Urinary Enzymes in Hyperoxaluric Rats. Jpn. J. Med. Sci. Biol. 1995, 48, 211-220. [CrossRef]

52. Malini, M.M.; Lenin, M.; Varalakshmi, P. Protective effect of triterpenes on calcium oxalate crystal-induced peroxidative changes in experimental urolithiasis. Pharmacol. Res. 2000, 41, 413-418. [CrossRef] [PubMed] 
53. Vidya, L.; Lenin, M.; Varalakshmi, P. Evaluation of the Effect of Triterpenes on Urinary Risk Factors of Stone Formation in Pyridoxine Deficient Hyperoxaluric Rats. Phytother. Res. 2002, 16, 514-518. [CrossRef] [PubMed]

54. Sakly, R.; Chaouch, A.; El Hani, A.; Najjar, M.-F. Effects of Intraperitoneally Administered Vitamin E and Selenium on Calcium Oxalate Renal Stone Formation: Experimental Study in Rat. Annales d'Urologie 2003, 37, 47-50. [CrossRef]

55. Sudhahar, V.; Veena, C.K.; Varalakshmi, P. Antiurolithic Effect of Lupeol and Lupeol Linoleate in Experimental Hyperoxaluria. J. Nat. Prod. 2008, 71, 1509-1512. [CrossRef] [PubMed]

56. Bashir, S.; Gilani, A.H. Antiurolithic Effect of Berberine Is Mediated through Multiple Pathways. Eur. J. Pharmacol. 2011, 651, 168-175. [CrossRef]

57. Vanachayangkul, P.; Chow, N.; Khan, S.R.; Butterweck, V. Prevention of Renal Crystal Deposition by an Extract of Ammi visnaga L. and Its Constituents Khellin and Visnagin in Hyperoxaluric Rats. Urol. Res. 2011, 39, 189-195. [CrossRef] [PubMed]

58. Vyas, N.; Argal, A. Antiurolithiatic Activity of Extract and Oleanolic Acid Isolated from the Roots of Lantana Camara on Zinc Disc Implantation Induced Urolithiasis. ISRN Pharmacol. 2013, 2013. [CrossRef]

59. Ghaeni, F.A.; Amin, B.; Hariri, A.T.; Meybodi, N.T.; Hosseinzadeh, H. Antilithiatic Effects of Crocin on Ethylene Glycol-Induced Lithiasis in Rats. Urolithiasis 2014, 42, 549-558. [CrossRef]

60. Chhiber, N.; Kaur, T.; Singla, S. Rottlerin, a Polyphenolic Compound from the Fruits of Mallotus Phillipensis (Lam.) Müll.Arg., Impedes Oxalate/Calcium Oxalate Induced Pathways of Oxidative Stress in Male Wistar Rats. Phytomedicine 2016, $23,989-997$. [CrossRef] [PubMed]

61. Heras, B.L.; Amesty, Á.; Estévez-Braun, A.; Hortelano, S. Metal Complexes of Natural Product Like-Compounds with Antitumor Activity. Anticancer. Agents Med. Chem. 2019, 19, 48-65. [CrossRef]

62. Merghoub, N.; El Btaouri, H.; Benbacer, L.; Gmouh, S.; Trentesaux, C.; Brassart, B.; Attaleb, M.; Madoulet, C.; Wenner, T.; Amzazi, S.; et al. Tomentosin Induces Telomere Shortening and Caspase-Dependant Apoptosis in Cervical Cancer Cells. J. Cell Biochem. 2017, 118, 1689-1698. [CrossRef] [PubMed]

63. Meléndez-Martínez, A.J. An Overview of Carotenoids, Apocarotenoids, and Vitamin A in Agro-Food, Nutrition, Health, and Disease. Mol. Nutr. Food Res. 2019, 63, 1801045. [CrossRef] [PubMed]

64. Comitato, R.; Ambra, R.; Virgili, F. Tocotrienols: A Family of Molecules with Specific Biological Activities. Antioxidants 2017, 6, 93. [CrossRef] [PubMed]

65. Drissi, A.; Bennani, H.; Giton, F.; Charrouf, Z.; Fiet, J.; Adlouni, A. Tocopherols and Saponins Derived from Argania Spinosa Exert, an Antiproliferative Effect on Human Prostate Cancer. Cancer Investig. 2006, 24, 588-592. [CrossRef] [PubMed] 